\title{
Assembling Ecological Pieces to Reconstruct the Conservation Puzzle of the Aegean Sea
}

\section{OPEN ACCESS}

Edited by:

Tito Monteiro da Cruz Lotufo, University of São Paulo, Brazil

Reviewed by:

Sergio Rossi,

University of Salento, Italy Heliana Teixeira,

University of Aveiro, Portugal

*Correspondence:

Maria Sini

mariasini@marine.aegean.gr

Specialty section:

This article was submitted to

Marine Evolutionary Biology, Biogeography and Species Diversity,

a section of the journal

Frontiers in Marine Science

Received: 12 July 2017 Accepted: 16 October 2017 Published: 17 November 2017

Citation:

Sini M, Katsanevakis S,

Koukourouvli N, Gerovasileiou V,

Dailianis T, Buhl-Mortensen L,

Damalas D, Dendrinos P, Dimas $X$, Frantzis A, Gerakaris V, Giakoumi S,

Gonzalez-Mirelis G, Hasiotis T,

Issaris Y, Kavadas SG,

Koutsogiannopoulos $D D$,

Koutsoubas D, Manoutsoglou E,

Markantonatou V, Mazaris $A D$,

Poursanidis D, Papatheodorou G, Salomidi M, Topouzelis K, Trygonis $V$, Vassilopoulou V and Zotou M (2017)

Assembling Ecological Pieces to Reconstruct the Conservation Puzzle of the Aegean Sea.

Front. Mar. Sci. 4:347.

doi: 10.3389/fmars.2017.00347

\begin{abstract}
Maria Sini ${ }^{1 *}$, Stelios Katsanevakis ${ }^{1}$, Nikoleta Koukourouvli ${ }^{2}$, Vasilis Gerovasileiou ${ }^{1,3}$, Thanos Dailianis ${ }^{1,3}$, Lene Buhl-Mortensen ${ }^{4}$, Dimitris Damalas ${ }^{5}$, Panagiotis Dendrinos ${ }^{6}$, Xenophon Dimas ${ }^{7}$, Alexandros Frantzis ${ }^{8}$, Vasilis Gerakaris ${ }^{9}$, Sylvaine Giakoumi ${ }^{10,11}$, Genoveva Gonzalez-Mirelis ${ }^{4}$, Thomas Hasiotis ${ }^{1}$, Yiannis Issaris ${ }^{9}$, Stefanos G. Kavadas ${ }^{5}$, David D. Koutsogiannopoulos ${ }^{12}$, Drosos Koutsoubas ${ }^{1}$, Evangelia Manoutsoglou ${ }^{1}$, Vessa Markantonatou ${ }^{1}$, Antonios D. Mazaris ${ }^{13}$, Dimitris Poursanidis ${ }^{1,14}$, George Papatheodorou ${ }^{7}$, Maria Salomidi ${ }^{9}$, Konstantinos Topouzelis ${ }^{1}$, Vasilis Trygonis ${ }^{1}$, Vassiliki Vassilopoulou ${ }^{5}$ and Maria Zotou ${ }^{1}$
\end{abstract}

${ }^{1}$ Department of Marine Sciences, University of the Aegean, Mytilene, Greece, ${ }^{2}$ Department of Geography, University of the Aegean, Mytilene, Greece, ${ }^{3}$ Institute of Marine Biological Resources and Inland Waters, Hellenic Center for Marine Research, Heraklion, Greece, ${ }^{4}$ Benthic Communities and Coastal Interactions, Institute of Marine Research, Bergen, Norway, ${ }^{5}$ Institute of Marine Biological Resources and Inland Waters, Hellenic Center for Marine Research, Athens, Greece, ${ }^{6} \mathrm{MOm} /$ Hellenic Society for the Study and Protection of the Monk Seal, Athens, Greece, ${ }^{7}$ Laboratory of Marine Geology and Physical Oceanography, Department of Geology, University of Patra, Patra, Greece, ${ }^{8}$ Pelagos Cetacean Research Institute, Athens, Greece, ${ }^{9}$ Institute of Oceanography, Hellenic Center for Marine Research, Athens, Greece, ${ }^{10}$ Université Côte d'Azur, Centre National de la Recherche Scientifique, Nice, France, ${ }^{11}$ ARC Centre of Excellence for Environmental Decisions, School of Biological Sciences, University of Queensland, Brisbane, QLD, Australia, ${ }^{12}$ Naturagraeca, Athens, Greece, ${ }^{13}$ Department of Ecology, School of Biology, Aristotle University of Thessaloniki, Thessaloniki, Greece, ${ }^{14}$ Institute of Applied and Computational Mathematics, Foundation for Research and Technology Hellas, Heraklion, Greece

The effective conservation of marine biodiversity through an integrated ecosystem-based management approach requires a sound knowledge of the spatial distribution of habitats and species. Although costly in terms of time and resources, acquiring such information is essential for the development of rigorous management plans and the meaningful prioritization of conservation actions. Located in the northeastern part of the Mediterranean, the Aegean Sea represents a stronghold for marine biodiversity. However, conservation efforts are hampered by the apparent lack of spatial information regarding marine habitats and species. This work is the first to address this knowledge gap by assembling, updating, and mapping information on the distribution of key ecological components. A range of data sources and methodological approaches was utilized to compile and complement the available data on 68 ecological features of conservation interest (58 animal species, six habitat categories, and four other vulnerable ecological features). A standardized data evaluation procedure was applied, based on five semi-quantitative data quality indicators in the form of a pedigree matrix. This approach assessed the sufficiency of the datasets and allowed the identification of the main sources of uncertainty, highlighting aspects that require further investigation. The overall dataset was found to be sufficient in terms of reliability and spatiotemporal relevance. However, it lacked in completeness, showing that there are still large areas of the Aegean that remain understudied, while further research is needed to elucidate the distribution patterns and conservation status of several ecological features; especially the less charismatic 
ones and those found in waters deeper than $40 \mathrm{~m}$. Moreover, existing conservation measures appear to be inadequate to safeguard biodiversity. Only $2.3 \%$ of the study area corresponds to designated areas for conservation, while 41 of the ecological features are underrepresented in these areas. Considering the high geomorphological complexity and transnational character of the Aegean Sea, this study does not offer a complete account of the multifaceted diversity of this ecoregion. Instead, it represents a significant starting point and a solid basis for the development of systematic conservation plans that will allow the effective protection of biodiversity within an adaptive management framework.

Keywords: ecological mapping, marine biodiversity distribution, spatial information, data evaluation, conservation planning, ecosystem-based management

\section{INTRODUCTION}

The ongoing deterioration of marine ecosystems and the subsequent decrease of biodiversity due to the cumulative impacts of anthropogenic pressures, alongside the everincreasing demand for marine space and natural resources, highlight the need for an integrated approach towards ecosystembased management. In an effort to halt biodiversity loss at a global scale, the Aichi Target 11 of the Convention on Biological Diversity (CBD) dictates that $10 \%$ of the sea should be protected by 2020 . This is to be achieved through the establishment of "effectively and equitably managed, ecologically representative and well-connected systems of protected areas and other effective area-based conservation measures" (Aichi Target 11, CBD). To this end, systematic conservation planning and marine spatial planning are currently considered as valuable tools to compensate the inadequacies of traditional sectoral management approaches (Possingham et al., 2006; Katsanevakis et al., 2011b). Spatial prioritization is essential when planning for conservation purposes, as it allows for the meaningful allocation of limited resources to specific management actions within welldefined areas, in a way that is most likely to produce effective conservation outcomes (Moilanen et al., 2009). At the same time, systematic conservation planning identifies priority areas for the establishment of Marine Protected Areas (MPAs), whilst reducing potential conflicts between conservation and socioeconomic objectives. This way, it maximizes the chances for the successful application of management measures (Margules and Pressey, 2000; Possingham et al., 2006). To achieve conservation targets however, this approach requires good knowledge of the spatial distribution of all major ecological and socio-economic components found within the areas of interest (Lourie and Vincent, 2004; Stelzenmüller et al., 2013; Levin et al., 2014). The detailed mapping of marine habitats and species is a core ingredient in the design and management of MPAs, as it ensures that the ecological features of conservation interest are sufficiently represented and protected (Margules and Pressey, 2000; Moilanen et al., 2009).

The Mediterranean Sea is a hotspot of marine biodiversity. This semi-enclosed sea hosts $\sim 17,000$ marine species, including a considerable number of endemic, threatened, or endangered species (Boudouresque, 2004; Coll et al., 2010), and a wide variety of habitat types encompassing several biocoenotic facies and species associations
(Fraschetti et al., 2008; UNEP/MAP-RAC/SPA, 2015b). It is also one of the most heavily impacted regions of the world, mainly due to historical and current overfishing, coastal development, pollution, climate change, and invasive species (Halpern et al., 2008; Coll et al., 2011; Micheli et al., 2013a). To date, a total of 1,231 marine sites of variable protection level have been identified in the Mediterranean Sea, corresponding to $7.14 \%$ of its total surface area (MedPAN and UNEP/MAP-SPA/RAC, 2016). Although existing well-enforced Mediterranean MPAs are effective at local scales (Giakoumi et al., 2017), they fail to accommodate the conservation of biodiversity at a regional scale through a unified approach (Giakoumi et al., 2012a). The majority of MPAs have been declared as such in an unsystematic manner, i.e., not following a common set of selection criteria and with little or no quantitative information to guide their designation (Giakoumi et al., 2011). Moreover, most of the MPAs are found in the western basin; in the rest of the Mediterranean, more than half of the sites have no administrative body or management plans (PISCO and UNS, 2016). As a result, a large part of the Mediterranean biodiversity is underrepresented in existing environmental management schemes, and remains effectively unprotected (MedPAN and UNEP/MAP-SPA/RAC, 2016; PISCO and UNS, 2016). This is especially true for the southern and eastern parts of the basin (including the Alboran, Eastern Ionian, Levantine, and Aegean seas), where a considerable lack of spatial information regarding ecological features, alongside several geopolitical and socio-economic factors, have dramatically delayed the implementation of rigid conservation actions (Giakoumi et al., 2012b; Katsanevakis et al., 2015).

The need to improve the effectiveness of conservation actions, both at a regional and at a local scale, has led to the proposal of several alternative/complementary prioritization schemes for the Mediterranean (Micheli et al., 2013b). Yet again, most of these initiatives primarily focus on the distribution of few commercial or flagship species and priority habitat types (e.g., seabirds, cetaceans, Posidonia oceanica beds), while other equally important but less known biotic features-such as sponges and rocky habitats-are typically ignored. In the Mediterranean, the distribution of habitats or physical features has often been used as surrogate for the distribution of species (see, for example, Giakoumi et al., 2013), but such an approach has often been criticized as inadequate to properly represent species biodiversity (Pierson et al., 2015; Jackson and Lundquist, 2016). New efforts 
seeking to encompass a wider spectrum of key habitat types and species are therefore urgently needed to harmonize and advance conservation practices in the region, and design adequate and representative networks of MPAs.

The objective of this study is to compile and map existing information on the geographic distribution of key marine habitats and protected species in the Aegean Sea. Located in the northeastern part of the Mediterranean, this marine area forms a distinct ecoregion (sensu Spalding et al., 2007) with a unique set of oceanographic, topographic, and biotic features. Although the Aegean Sea is a hotspot for Mediterranean marine biodiversity (Coll et al., 2010) and has been the focus of marine scientific research since antiquity (Voultsiadou and Vafidis, 2007), there is still an apparent lack of spatial information regarding the distribution of its marine ecological features. Over the last 30 years, a significant amount of research has been conducted on different taxonomic groups and habitat types. However, this information is greatly scattered among a broad range of data sources (scientific documents, technical reports, and circumstantial inventories), and a large proportion is not publicly available or presents important gaps in terms of spatial information. Moreover, despite the high ecological significance of the Aegean Sea, existing marine-nature protection schemes are mainly restricted to "paper parks" (i.e., protected areas that are only designated on paper, lacking any formal management; Abdulla et al., 2008), and there is no cohesive conservation plan to counterbalance the multiple anthropogenic pressures exerted upon its coastal and marine ecosystems (e.g., Coll et al., 2011; Micheli et al., 2013a). This work constitutes the first coordinated effort to assemble, integrate, and update available spatial information on the distribution of key ecological features in the Aegean Sea. The quality of the data obtained was further evaluated based on a semi-quantitative standardized procedure, in order to assess their credibility as a basis for the development of future conservation plans according to a systematic approach.

\section{METHODS}

\section{Study Area}

The study area encompasses the international and Greek territorial waters of the Aegean Sea (NE Mediterranean), with the southern limits being roughly delimited by the $2,000 \mathrm{~m}$ isobath located southwards off Crete, Karpathos, Rhodes, and Megisti (Kastelorizo) islands (Figure 1). Situated at an area where the Asian, European, and African plates converge, the Aegean seafloor is characterized by an intricate geomorphology that reflects past geologic history and recent geodynamic processes (Sakellariou and Papoulia, 2005). Shallow shelves, deep basins, and troughs alternate throughout the area, the deepest point being 2,500 $\mathrm{m}$ (Sakellariou et al., 2005). The Aegean Sea has a distinctive insular character with more than 1,400 islands or islets, while its extensive coastline comprises several landforms, including sandy beaches, rocky shores, cliffs, coastal lagoons and deltaic systems (Anagnostou et al., 2005), as well as a notable variety of coastal and marine habitat types.

The Aegean ecoregion is divided into two distinct sectors (commonly referred to as basins), the North and South
Aegean, with the Cyclades islands plateau being the main dividing physical feature with a maximum depth of $400 \mathrm{~m}$ (Sakellariou et al., 2005). This distinction is also reflected in the seawater circulation patterns, temperature, and productivity levels (Ignatiades et al., 2002; Lykousis et al., 2002; Zervakis et al., 2004). The S Aegean surface waters are characterized as more oligotrophic, as they are affected by the northward flowing, warm and high-salinity waters of the Levantine basin with minimum freshwater inputs from rivers; the $\mathrm{N}$ Aegean surface waters are more influenced by the cold, brackish Black Sea waters, and the nutrient-rich freshwater discharge of the major rivers draining southeastern Europe (Lykousis et al., 2002; Zervakis et al., 2004).

\section{Scope of the Study}

This study was carried out in the framework of the MARISCA project (2015-2016; www.marisca.eu) whose ultimate goal was to propose a network of MPAs and protection zones in the context of an integrated Marine Spatial Planning approach for the conservation of marine biodiversity and the management of marine-related human activities in the Aegean Sea. To fulfill this goal, this large-scale project focused on combining information of existing ecological, socio-economic, and spatial management data, in order to proceed with the establishment of a transparent system of spatial prioritization using the software MARXAN with Zones (Watts et al., 2009). As a first step into this process, this paper presents the ecological mapping and data quality evaluation of key marine features in the area, in order to establish the ecological basis upon which to set up alternative conservation scenarios; the latter will be addressed in future published work.

\section{Key Ecological Features}

A selection of key ecological components (species, habitats, and other vulnerable ecological features) was primarily compiled based on national or international legislation and conventions, alongside experts' knowledge regarding their occurrence in the study area. Specifically, the choice of marine habitat types (hereafter referred to as habitats) was based on the definitions provided by the European Union Habitats Directive (92/43/EEC) and the EUNIS classification system of European habitats. The list of animal species was limited to those that are under strict protection status, and whose collection and deliberate capture or killing is prohibited according to the Annex II of the "Protocol for Specially Protected Areas and Biological Diversity in the Mediterranean" of the Barcelona Convention, the Annex IV of the EU Habitats Directive (92/43/EEC), the Annex I of the EU Birds Directive (2009/147/EEC), the Annex II of the Bern Convention, and the Appendix II of the Greek Presidential Decree $67 / 81$ on the protection of native flora and wild fauna. An additional group of other vulnerable ecological featureswhich do not strictly fit the definition of a "habitat"-were also considered, as they represent structurally important biotic components that are characterized by high vulnerability to anthropogenic stressors, slow growth rates, and low resilience. Overall, information was collected for six habitats, four other vulnerable ecological features, and fifty eight protected animal species (Tables 1, 2). 


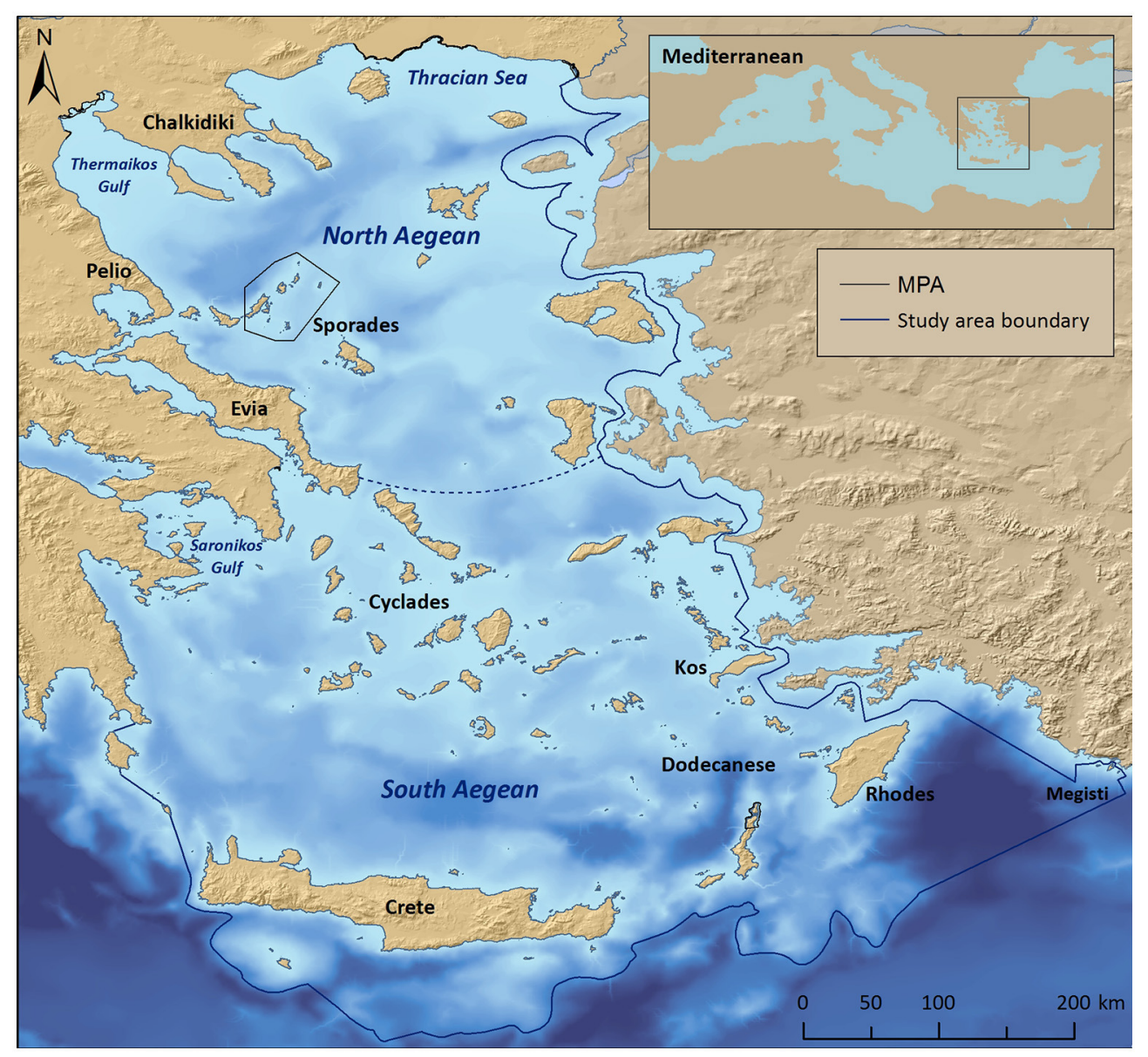

FIGURE 1 | Map of the Aegean Sea, depicting the study area boundary, the National Marine Park of Alonissos Northern Sporades, as well as other coastal MPAs. The dotted line indicates a notional delimiter between the North and South Aegean basins.

\section{Description of Data Sources}

Spatial information regarding the past and present distribution patterns of key ecological features was compiled using an assortment of different sources: (i) Scientific literaturePublished information was collated based on a thorough review of scientific literature, including peer-reviewed articles, books, monographs, and Ph.D. theses. (ii) Past projects-Datasets from past projects provided by universities, research institutes, and non-governmental organizations were scrutinized for unpublished data. (iii) Online databases-Online scientific databases, mapping services, citizen science networks, and diving guides were utilized to recover additional information and maximize the spatial extent of our data. (iv) Interviews and questionnaires-Dedicated questionnaires with embedded images of key species and habitats were specifically designed to collect information from divers, diving centers, university students, marine researchers, and fishers throughout Greece (see details in Supplementary Files 1, 4). (v) Expert judgmentThe delineation of important areas for certain wide-ranging, highly mobile species was achieved through collaboration with experts who are engaged in the long-term monitoring of these populations. (vi) Remote sensing-Medium resolution satellite images (Landsat-8) were used to acquire new data for marine habitats of the infralittoral zone $(<30 \mathrm{~m}$ depth; see Supplementary File 1 for a detailed description of the methodological framework). (vii) New field data-During 2016, a series of dedicated field expeditions were organized in order to validate and update existing records, as well as to explore understudied areas at selected sites of the Aegean Sea. The expeditions included SCUBA diving surveys for the investigation of hard substrates at depths shallower than $40 \mathrm{~m}$, use of high resolution side scan sonar for seabed imaging, Unmanned Aerial Vehicles (UAVs) surveys for validation of satellite images, Remotely Operated Vehicles (ROVs), and underwater drop camera dives for ground-truth sampling and assessment of the deeper bathymetric limits of certain habitats (e.g., $P$. oceanica beds and coralligenous formations). The respective New field data were obtained from a total of 135 sites sampled during these expeditions (see Supplementary File 1 for analytical information on the field methods). A detailed description of the data sources used per ecological feature, alongside the corresponding methodological considerations and data assumptions, are provided in the paragraphs that follow. 
TABLE 1 | List of marine species whose distribution was investigated in the present study, and the corresponding protection status according to the Annexes of international conventions and directives.

\begin{tabular}{|c|c|c|c|c|c|}
\hline $\begin{array}{l}\text { Taxonomic } \\
\text { group }\end{array}$ & Species & $\begin{array}{l}\text { National and international } \\
\text { laws, conventions and } \\
\text { directives }\end{array}$ & Type of data & $\begin{array}{l}\text { In national } \\
\text { parks (\%) }\end{array}$ & $\begin{array}{l}\text { In Natura } \\
2000 \text { sites } \\
(\%)\end{array}$ \\
\hline \multirow[t]{9}{*}{ Porifera } & Aplysina spp. & Bc II; BeC ॥ & Points & 1 & 24 \\
\hline & Axinella cannabina (Esper, 1794) & $\mathrm{Bc} \|$ & Points & 2 & 21 \\
\hline & Axinella polypoides (Schmidt, 1862) & $\mathrm{Bc}\|; \mathrm{BeC}\|$ & Points & 14 & 37 \\
\hline & Geodia cydonium (Linnaeus, 1767) & $\mathrm{BC} \|$ & Points & 0 & 12 \\
\hline & Petrobiona massiliana (Vacelet and Lévi, 1958) & Bc II; BeC ॥ & Points & 0 & 0 \\
\hline & Sarcotragus foetidus (Schmidt, 1862) & $\mathrm{Bc} \|$ & Points & 1 & 25 \\
\hline & Sarcotragus pipetta (Schmidt, 1868) & $\mathrm{Bc} \|$ & Points & 0 & 0 \\
\hline & Tethya aurantium (Pallas, 1766) & $\mathrm{Bc} \|$ & Points & 3 & 13 \\
\hline & Tethya citrina (Sarà and Melone, 1965) & $\mathrm{Bc} \|$ & Points & 7 & 30 \\
\hline \multirow[t]{6}{*}{ Anthozoa } & $\begin{array}{l}\text { Antipathella subpinnata (Ellis and Solander, } \\
\text { 1786) }\end{array}$ & $\mathrm{Bc} \|$ & Points & 0 & 0 \\
\hline & Antipathes dichotoma (Pallas, 1766) & $\mathrm{Bc} \|$ & Points & 0 & 0 \\
\hline & Callogorgia verticillata (Pallas, 1766) & $\mathrm{Bc} \|$ & Points & 33 & 33 \\
\hline & Cladocora caespitosa (Linnaeus, 1767) & $\mathrm{Bc} \|$ & Points & 2 & 26 \\
\hline & Leiopathes glaberrima (Esper, 1788) & $\mathrm{Bc} \|$ & Points & 0 & 0 \\
\hline & Savalia savaglia (Bertoloni, 1819) & $\mathrm{Bc}\|; \mathrm{BeC}\|$ & Points & 20 & 40 \\
\hline \multirow[t]{9}{*}{ Mollusca } & Charonia variegata (Lamarck, 1816) & $\mathrm{Bc}\|; \mathrm{BeC}\|$ & Points & 0 & 31 \\
\hline & Erosaria spurca (Linnaeus, 1758) & Bc I; BeC ॥; Pd ॥ & Points & 0 & 19 \\
\hline & Lithophaga lithophaga (Linnaeus, 1758) & Bc II; Hd IV & Points & 4 & 27 \\
\hline & Luria lurida (Linnaeus, 1758) & $\mathrm{Bc}\|; \mathrm{BeC}\| ; \mathrm{Pd} \|$ & Points & 1 & 22 \\
\hline & Mitra zonata (Marryat, 1819) & $\mathrm{Bc}\|; \mathrm{BeC}\|$ & Points & 0 & 0 \\
\hline & Pholas dactylus (Linnaeus, 1758) & $\mathrm{BC} \|$ & Points & 0 & 15 \\
\hline & Pinna nobilis (Linnaeus, 1758) & Bc I; BeC I; Hd IV; Pd II & Points & 2 & 34 \\
\hline & Tonna galea (Linnaeus, 1758) & $\mathrm{Bc}\|; \mathrm{BeC}\| ; \mathrm{Pd} \|$ & Points & 1 & 15 \\
\hline & Zonaria pyrum (Gmelin, 1791) & $\mathrm{Bc}\|; \mathrm{BeC}\| ; \mathrm{Pd} \|$ & Points & 0 & 0 \\
\hline \multirow[t]{2}{*}{ Echinodermata } & Centrostephanus longispinus (Philippi, 1845) & $\mathrm{Bc} I I ; \mathrm{BeC} I I ; \mathrm{Hd} I V$ & Points & 6 & 27 \\
\hline & Ophidiaster ophidianus (Lamarck, 1816) & $\mathrm{Bc}\|; \mathrm{BeC}\|$ & Points & 1 & 19 \\
\hline \multirow[t]{3}{*}{ Actinopterygii } & Hippocampus guttulatus (Cuvier, 1829) & $\mathrm{Bc}\|; \mathrm{BeC}\|$ & Points & 0 & 19 \\
\hline & Hippocampus hippocampus (Linnaeus, 1758) & $\mathrm{Bc}\|; \mathrm{BeC}\|$ & Points & 0 & 12 \\
\hline & Hippocampus spp. & $\mathrm{Bc}\|; \mathrm{BeC}\|$ & Points & 0 & 3 \\
\hline \multirow[t]{16}{*}{ Elasmobranchii } & Gymnura altavela (Linnaeus, 1758) & $\mathrm{Bc} \|$ & Points & 0 & 83 \\
\hline & Mobula mobular (Bonnaterre, 1788) & Bc II; BeC II; Pd II & Points & 0 & 0 \\
\hline & Dipturus batis (Linnaeus, 1758) & $\mathrm{Bc} \|$ & Points & 0 & 0 \\
\hline & Leucoraja circularis (Couch, 1838) & $\mathrm{Bc} \|$ & Points & 0 & 0 \\
\hline & Leucoraja melitensis (Clark, 1926) & $\mathrm{Bc} \|$ & Points & 0 & 0 \\
\hline & Rostroraja alba (Lacepède, 1803) & $\mathrm{Bc} \|$ & Points & 0 & 0 \\
\hline & Rhinobatos rhinobatos (Linnaeus, 1758) & Bc $\|$ & Points & 0 & 0 \\
\hline & Tetronarce nobiliana (Bonaparte, 1835) & $P d \|$ & Points & 3 & 7 \\
\hline & Galeorhinus galeus (Linnaeus, 1758) & $\mathrm{Bc} \|$ & Points & 0 & 0 \\
\hline & Heptranchias perlo (Bonnaterre, 1788) & $\mathrm{Bc}\|; \mathrm{Pd}\|$ & Points & 0 & 0 \\
\hline & Hexanchus griseus (Bonnaterre, 1788) & $P d \|$ & Points & 9 & 9 \\
\hline & Isurus oxyrinchus (Rafinesque, 1810) & $\mathrm{Bc} \|$ & Points & 0 & 0 \\
\hline & Oxynotus centrina (Linnaeus, 1758) & $\mathrm{Bc} \|$ & Points & 0 & 0 \\
\hline & Squatina aculeata (Cuvier, 1829) & $\mathrm{Bc} \|$ & Points & 0 & 0 \\
\hline & Squatina oculata (Bonaparte, 1840) & $\mathrm{Bc} \|$ & Points & 0 & 0 \\
\hline & Squatina squatina (Linnaeus, 1758) & $\mathrm{Bc} \|$ & Points & 0 & 0 \\
\hline
\end{tabular}


TABLE 1 | Continued

\begin{tabular}{|c|c|c|c|c|c|}
\hline $\begin{array}{l}\text { Taxonomic } \\
\text { group }\end{array}$ & Species & $\begin{array}{l}\text { National and international } \\
\text { laws, conventions and } \\
\text { directives }\end{array}$ & Type of data & $\begin{array}{l}\text { In national } \\
\text { parks (\%) }\end{array}$ & $\begin{array}{l}\text { In Natura } \\
2000 \text { sites } \\
(\%)\end{array}$ \\
\hline Reptilia & Caretta caretta (Linnaeus, 1758)* & Bc II; BeC II; Hd II, IV; Pd II & Polygons & 0 & 60 \\
\hline \multirow[t]{8}{*}{ Mammalia } & Monachus monachus (Hermann, 1779) & Bc II; BeC I; Hd II, IV, V; Pd II & Polygons & 70 & 93 \\
\hline & Tursiops truncatus (Montagu, 1821)* & Bc II; BeC II; Hd II, IV; Pd II & Polygons & 6 & 9 \\
\hline & Delphinus delphis (Linnaeus, 1758) & Bc II; BeC II; Hd IV; Pd II & Polygons & 6 & 9 \\
\hline & Stenella coeruleoalba (Meyen, 1833) & Bc II; BeC II; Hd IV; Pd II & Polygons & 4 & 6 \\
\hline & Grampus griseus (G. Cuvier, 1812) & Bc II; BeC II; Hd IV & Polygons & 2 & 2 \\
\hline & Physeter macrocephalus (Linnaeus, 1758) & Bc II; BeC II; Hd IV & Polygons & 0 & 1 \\
\hline & Ziphius cavirostris (Cuvier, 1823) & $\mathrm{Bc} I I ; \mathrm{BeC} I I ; \mathrm{Hd}$ IV & Polygons & 3 & 4 \\
\hline & Phocoena phocoena relicta (Abel, 1905) & $\mathrm{Bc}\|; \mathrm{BeC}\| ; \mathrm{Hd}\|, \mathrm{IV} ; \mathrm{PD}\|$ & Polygons & 1 & 3 \\
\hline \multirow[t]{5}{*}{ Aves } & Larus audouinii (Payraudeau, 1826) & $\mathrm{Bc}\|; \mathrm{BeC}\| ; \mathrm{Bd} \mathrm{I}$ & Polygons & 29 & 38 \\
\hline & $\begin{array}{l}\text { Phalacrocorax aristotelis desmarestii } \\
\text { (Payraudeau, 1826) }\end{array}$ & $\mathrm{Bc}\|; \mathrm{BeC}\| ; \mathrm{Bd} \mathrm{I}$ & Polygons & 27 & 37 \\
\hline & Calonectis diomedea (Scopoli, 1769) & $\mathrm{Bc}$ II; BeC II Bd I & Polygons & 36 & 43 \\
\hline & Puffinus yelkouan (Acerbi, 1827) & $\mathrm{Bc}$ II; BeC I; Bd I & Polygons & 25 & 34 \\
\hline & Hydrobates pelagicus (Linnaeus, 1758) & $\mathrm{Bc}\|; \mathrm{BeC}\| ; \mathrm{Bd} \mathrm{I}$ & Polygons & 0 & 1 \\
\hline
\end{tabular}

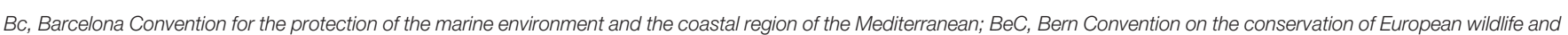

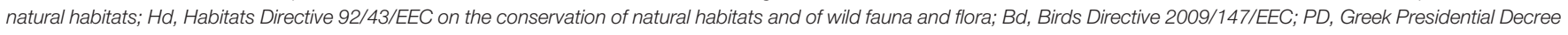

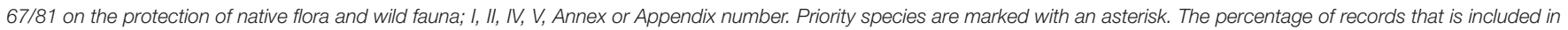
designated marine parks or Natura 2000 sites is indicated in the last two columns.

TABLE 2 | List of key marine habitat types and other vulnerable ecological features whose distribution was investigated in the present study, and their associated habitat type codes according to two habitat classification systems: the Habitats Directive 92/43/EEC and the European Nature Information System (EUNIS).

\begin{tabular}{|c|c|c|c|c|c|}
\hline & $\begin{array}{l}\text { Habitat's directive } \\
\text { codes }\end{array}$ & EUNIS codes & Type of data & $\begin{array}{l}\text { In national } \\
\text { parks }(\%)\end{array}$ & $\begin{array}{c}\text { In Natura } 2000 \\
\text { sites (\%) }\end{array}$ \\
\hline \multicolumn{6}{|l|}{ KEY HABITATS } \\
\hline Coastal lagoons ${ }^{\star}$ & 1150 & X02; X03 & Polygons & 29 & 53 \\
\hline Soft substrates & Included in 1110 & $\begin{array}{l}\text { Several codes that refer to } \\
\text { coastal sands and detritic } \\
\text { sediments }\end{array}$ & Polygons & 4 & 25 \\
\hline Seagrass beds (mainly P. oceanica*) & $\begin{array}{l}\text { Mainly referring to } \\
1120\end{array}$ & A $5.531 ;$ A 5.535 & Polygons & 2 & 27 \\
\hline Hard substrates & 1170 & A3.23; A3.33 & Polygons & 3 & 22 \\
\hline Submarine structures made by leaking gasses & 1180 & A3.73; A4.73; A5.71 & Polygons & 0 & 2 \\
\hline Partially or fully submerged caves & 8330 & A1.44; A3.71; A4.74 & Points & 7 & 49 \\
\hline \multicolumn{6}{|c|}{ OTHER VULNERABLE ECOLOGICAL FEATURES } \\
\hline Rhodolith beds & Included in 1110 & A5.51 & Points and Polygons & 3 & 25 \\
\hline Coralligenous formations & Included in 1170 & A 4.32; A4.26 & Points and Polygons & 2 & 15 \\
\hline Corals of the sublittoral zone & $\begin{array}{l}\text { Included in 1170; } \\
1110\end{array}$ & A4.26 & Points & 16 & 25 \\
\hline Corals of the bathyal zone & Included in 1170 & A6.6; A6.61 & Points & 18 & 18 \\
\hline
\end{tabular}

Priority habitat types are marked with an asterisk. The percentage of records that is included in designated marine parks or Natura 2000 sites is indicated in the last two columns.

\section{Key Habitats \\ Coastal lagoons}

Coastal lagoons refer to all expanses of shallow coastal salt water which are wholly or partially separated from the sea by the deposits of sand, shingle or rocks (as defined by the $92 / 43 /$ EEC), also including those that are found in the proximity of deltaic systems. Geographic information on this habitat type was extracted from general purpose catalogs, scientific documents (e.g., Nicolaidou et al., 2005; General Administration for Sustainable Fisheries, 2016), online databases (WWF, 2016), and Google Earth.

\section{Marine habitats of the infralittoral zone $(<30 \mathrm{~m})$-seagrass beds, soft substrates and hard substrates}

Satellite images were used to acquire new data for the mapping of three generic habitat types; seagrass beds (consisting primarily of $P$. oceanica, but also some Cymodocea nodosa meadows), soft substrates (containing sandy or muddy sediments, small pebbles, 
and organogenic/detritic substrates), and rocky substrates found in waters shallower than $30 \mathrm{~m}$. Spatial data for the aforementioned habitat types were extracted from Landsat- 8 satellite images using image processing techniques. The Landsat8 habitat-classified images were delivered as geo-referenced data with a $30 \mathrm{~m}$ (pixel size) spatial resolution, and $\sim 10 \mathrm{~m}$ positional accuracy. Aerial inspection utilizing a UAV (i.e., quadcopter), ground-truth sampling, and experts' knowledge, were used to validate the acquired information at selected sites.

\section{Marine caves}

Distribution data of entirely- or semi-submerged marine caves were mainly extracted from the pan-Mediterranean marine cave shapefile provided by Giakoumi et al. (2013). Additional information was obtained during regional biodiversity assessments (Gerovasileiou et al., 2015), interviews and questionnaires with divers, as well as diving surveys conducted during the present study.

\section{Submarine structures made by leaking gases}

The spatial data of "submarine structures made by leaking gases" (Habitat Type 1180 sensu 92/43/EEC) was acquired from past geological surveys focusing on well-known underwater hydrothermal vent sites along the Aegean volcanic arc (Dando et al., 2000; Sigurdsson et al., 2006; Nomikou et al., 2012, 2013; Kilias et al., 2013). These structures are characterized by the presence of chimneys, cones, bubbling reefs, and other conspicuous submarine structures (Baggini et al., 2014, 2015). Besides the frequent presence of microbial mats and scattered observations of deep-sea sponges and anthozoans, little biodiversity data are yet available for these ecosystems.

\section{Other Vulnerable Ecological Features Rhodolith beds}

According to the definitions provided by the Habitats Directive 92/43/EEC and the Barcelona Convention, rhodolith beds refer to mobile substrates largely composed of variably-sized growth forms of unattached algal species of the Corallinaceae and Peyssonneliaceae families, and are commonly found in association with coarse sands and fine gravels. Their depth distribution ranges from the upper infralittoral to the lower circalittoral zone ( $<20-180 \mathrm{~m}$; Barberá et al., 2003), while their average depth range within the Mediterranean is between 30 and $75 \mathrm{~m}$ (Basso et al., 2016a). The majority of records regarding their distribution in the Aegean Sea come from published bionomic surveys (Pérès and Picard, 1958) and broad-scale mapping (Martin et al., 2014; Basso et al., 2016b). Additional information was extracted from past projects and new field data, all of which refer to dedicated small-scale seabed mapping surveys, using a combination of hydroacoustic technology, ROVs, underwater drop cameras, and seabed samples (Supplementary Files 1, 4).

\section{Coralligenous formations}

Mediterranean coralligenous formations refer to biogenic structures made up of encrusting coralline algae and calcareous animal material. They typically develop under dim light conditions at depths ranging from 20 to $120 \mathrm{~m}$, either (a) as outcrops of rocky substrates (i.e., coralligenous of the littoral rock), or (b) as banks/platforms/minute reefs (sensu Georgiadis et al., 2009) surrounded by sedimentary substrates or even sandy bottoms (Ballesteros, 2006; Georgiadis et al., 2009). The geographic distribution of coralligenous formations in the Aegean Sea was mainly based on data provided by previous mapping efforts of variable spatial resolution (e.g., Georgiadis et al., 2009; Fakiris, 2012; Giakoumi et al., 2013; Martin et al., 2014; Papatheodorou et al., 2014; Dimas et al., 2015; Geraga et al., 2016), and ecological assessments (e.g., Sini et al., 2015; Supplementary File 4). New information on coralligenous formations of the littoral rock found at depths shallower than $40 \mathrm{~m}$ was acquired through interviews and questionnaires with divers, and during the SCUBA diving surveys of the present study. Regarding coralligenous platforms, new data were collected based on the re-evaluation of information obtained during past projects utilizing geo-acoustic systems (see technical reports in Supplementary File 4); this information led to the selection of specific locations for ROV targeted dives at the southern parts of the Cyclades plateau, which enabled the ground-truthing of past acoustic data, and offered further insights regarding the existence of coralligenous platforms in the study area.

\section{Corals of the sublittoral zone (CSZ)}

Across the Mediterranean, arborescent corals are found over a wide range of habitat types, from shallow photophilous rocky substrates and biogenic reefs, to coralligenous formations, coarse gravel sediments, rhodolith beds, marine caves, and the deep slopes of seamounts. Some of these species are known to develop dense populations which are conceived as discrete biocoenotic facies based on the dominance of different gorgonian or coral species (UNEP/MAP-RAC/SPA, 2015b). Given their major contribution in forming seascapes of high structural complexity, their vulnerability to a wide range of stressors, and the fact that they may appear in several habitat types that are not being addressed in the present study, herein they were treated as a distinct ecological feature. The "corals of the sublittoral zone" dataset refers to all arborescent corals whose occurrence in the Aegean Sea is primarily known from waters shallower than $200 \mathrm{~m}$. These include nine gorgonian species (Eunicella cavolini, E. singularis, E. verrucosa, Paramuricea clavata, P. macrospina, Leptogorgia sarmentosa, Spinimuricea klavereni, and Villogorgia bebrycoides), as well as the red coral Corallium rubrum. According to the IUCN Red List of threatened Mediterranean Anthozoans (Otero et al., 2017), the aforementioned Eunicella species are ranked as Near Threatened, P. clavata as Vulnerable, C. rubrum as Endangered, while P. macrospina, S. klavereni, and $V$. bebrycoides as Data Deficient. The main part of the corresponding dataset comprises information obtained from scientific literature and interviews with SCUBA divers. Few additional records were collected from online sources, datasets from past projects, and diving surveys.

\section{Corals of the bathyal zone (CBZ)}

This dataset includes information on all arborescent coral species that are found at depths greater than $200 \mathrm{~m}$ (i.e., 
the bathyal zone). Distribution data were extracted from few scattered records found in the scientific literature (Pérès and Picard, 1958; Zibrowius, 1979, 1980; Vafidis et al., 1994; Smith et al., 2009; Salomidi et al., 2010) and online databases. These refer to the rare occurrences of individual specimens of the scleractinians Cladopsammia rolandi, Dendrophyllia cornigera, D. ramea, as well as the gorgonians Isidella elongata, Swiftia pallida, and S. dubia; Isidella elongata is considered to be Critically Endangered, D. cornigera as Endangered, D. ramea as Vulnerable, while C. rolandi and S. pallida as Data Deficient (Otero et al., 2017). Fossilized remnants of rich deep-water coral communities discovered along the deep continental margins of Crete, Karpathos, and Rhodes islands by Taviani et al. (2011), were also included, in order to provide some insights on the past distribution of these biotic assemblages, and a basis for comparisons with the present distribution of other anthozoan species.

\section{Protected Species \\ Porifera}

The Porifera dataset contains information on nine taxa of conservation interest (Table 1). Most of the information comes from scientific literature, as well as from new records of field surveys and interviews conducted during the present study. Scientific literature includes research that specifically focuses on sponges (e.g., Voultsiadou, 1986; Kefalas and CastritsiCatharios, 2007; Voultsiadou et al., 2008, 2010; Gerovasileiou and Voultsiadou, 2012), as well as studies with a broader ecological scope (e.g., Pérès and Picard, 1958; Antoniadou et al., 2006; Salomidi et al., 2016). Scattered records found in the technical reports of past projects and online databases were also considered, but account only for a small fraction of the dataset.

\section{Anthozoa}

The protected Anthozoa dataset includes information on seven strictly protected taxa; one hexacoral and six octocorals (Table 1). The bulk of the dataset consists of records regarding C. caespitosa, the only endemic scleractinian coral of the Mediterranean known to form reefs in the infralittoral zone (Laborel, 1987). C. caespitosa distribution data were primarily obtained through interviews and field observations conducted in the present study, while additional information originated from past projects or scientific literature. Available data on the remaining six octocorals were restricted to four scientific documents (Vafidis et al., 1994; Salomidi et al., 2009, 2010; Taviani et al., 2011) and few scattered records from online databases and interviews.

\section{Mollusca}

The Mollusca dataset involves nine protected species; six gastropods and three bivalves (Table 1). Purely scientific data sources (i.e., scientific literature, field observations during past or present projects) and information provided through interviews with experts or non-experts had an overall equal contribution to this dataset. However, with the exception of Pinna nobilis, which is the most commonly studied/recorded mollusk considered herein (e.g., Katsanevakis et al., 2008;
Katsanevakis and Thessalou-Legaki, 2009; Vafidis et al., 2014), little dedicated research has been conducted or published on the remaining species, for which distribution data is primarily anecdotal.

\section{Echinodermata}

Data on the two protected Echinodermata species, Centrostephanus longispinus and Ophidiaster ophidianus, were mainly collected through interviews with divers. Additional records were obtained from past projects and new field data, while relevant information in scientific documents was restricted to few observations reported during wider biodiversity assessments.

\section{Osteichthyes-Hippocampus spp.}

The geographic distribution of the two Hippocampus species, $H$. guttulatus and $H$. hippocampus, was mainly based on information extracted from fisheries surveys conducted by the Hellenic Centre for Marine Research (HCMR; Petrakis et al., 2001, 2009) over the time period 2000-2001 (8 months) and 2008-2009 (6 months). All observations were made onboard commercial boat seiners targeting Spicara smaris at depths ranging from 5 to $40 \mathrm{~m}$. A substantial amount of information was also collected through interviews conducted during the present study, whereas the contribution of data from online databases and scientific literature was limited.

\section{Pelagic and bentho-pelagic Elasmobranchii (Large sharks)}

Large sharks, being highly migratory by nature (Carrier et al., 2004), are regarded as transient visitors in the Aegean Sea. Data on the three species of large sharks (Galeorhinus galeus, Heptranchias perlo, Isurus oxyrinchus) considered herein is based on information collected during past projects over a time period between 1998 and 2005 (Megalofonou et al., 2000) and scientific literature (Damalas, 2002, 2009; Damalas and Megalofonou, 2012). Data refer to observations made onboard commercial fishing vessels targeting large pelagic fish (mainly swordfish and tuna); hence, sharks were occasional by-catches and not the direct focus of those studies.

\section{Benthic Elasmobranchii (Sharks, rays, and skates)}

Data originate from a series of fishery-dependent and independent surveys conducted since the 1990's by HCMR. Fishery-dependent surveys were realized during the period 2002-2015 (with some annual gaps) in the framework of the national obligation to monitor the fisheries sector based on the requirements of the EU Common Fisheries Policy (Data Collection Regulation-COM 1543/2000; Data Collection Framework-COM 199/2008). Additional fishery-independent surveys were conducted through several projects financed by national or international funds focusing on the benthic communities of Greek waters (see Supplementary File 4 for a full list of projects). The most long-standing fisheries monitoring project is MEDITS (Bertrand et al., 2000), implemented since 1994 in all EU Mediterranean countries following a common protocol. In all cases, data were collected by trained observers onboard commercial bottom trawlers targeting demersal assemblages. All of these studies are only available in the form 
of hardcopy technical reports, accessible through the HCMR library (library.hcmr.gr/hcmr-library/).

\section{Cetacea}

Seven cetacean species are resident in the Aegean Sea (Table 1; Frantzis, 2009). Three of them have their Mediterranean population classified as Endangered (Physeter macrocephalus, Delphinus delphis, Phocoena phocoena relicta) in the IUCN Red List (Reeves and Notarbartolo di Sciara, 2006). Spatial information on the distribution of the seven cetacean species was provided by the Pelagos Cetacean Research Institute. Specifically, the delineation of important areas for each of the seven species was based on distribution data obtained through field observations over the last 15 years, habitat suitability modeling (Giannoulaki et al., 2016), and expert judgment (for optimal polygon limits). The aforementioned field observations include geo-referenced sightings of cetacean groups which were mainly recorded during dedicated visual-acoustic surveys, or as opportunistic observations accompanied by photographic material for the identification/verification of species.

\section{The Mediterranean monk seal Monachus monachus}

The population size of the endangered monk seal in Greece is currently estimated at $\sim 300$ individuals (Karamanlidis et al., 2015). Nowadays, monk seal sightings are widely distributed throughout the Aegean and the Ionian seas (MOm, unpublished data). Important pupping areas for the species in the study area have been determined based on published records (Dendrinos et al., 2008; Dendrinos, 2011) and unpublished data stemming from long-term research conducted by MOm/Hellenic Society for the Study and Protection of the Monk Seal.

\section{The loggerhead sea turtle Caretta caretta}

Important nesting sites of the loggerhead sea turtle Caretta caretta in the Aegean Sea were derived from selected scientific documents (Casale and Margaritoulis, 2010; Almpanidou et al., 2016). The size of nesting sites was obtained using several published sources (summarized in Almpanidou et al., 2016), and was based on the mean annual nest numbers per site across multiple nesting seasons, or-for sites where no such time series was available-on the most recent records of nest abundance.

\section{Seabirds}

Geospatial information on the distribution of Important Bird Areas (IBAs) for marine avifauna was extracted from the Greek marine IBA inventory (Fric et al., 2012). The corresponding shapefile presents important sites for the five seabirds considered in this study (Table 1). According to Fric et al. (2012), the delineation of marine IBAs was based on information that has been collected over the past 15 years, using a standardized protocol for data collection, analysis, and statistical modeling, and applying the same criteria for the identification of candidate sites as those utilized for terrestrial or freshwater IBAs.

\section{Data Mapping}

To enable the construction of illustrative maps and the comprehensive evaluation of the data sources, all information was digitized and organized into a collective geographic database using the Pan-European grid-ETRS89 Lambert Azimuthal Equal Area projection coordinate reference system. Separate feature classes (points or polygons) were created for each ecological feature. To illustrate the number of ecological features found in different parts of the Aegean Sea, a heat map was constructed using a $2 \times 2 \mathrm{~km}$ LAEA grid for national waters, and a $10 \times 10 \mathrm{~km}$ grid for international waters, corresponding to a total of 29,628 grid cells covering the entire study area. The proportion of the different ecological features that were recorded within existing Marine Parks and Natura 2000 sites (the EU network of protected areas) was estimated based on the total number of records found within or outside these areas for point data, and total area cover for polygon data.

\section{Data Quality}

The aim of the data quality assessment was to evaluate the origin of the data, identify the main sources of uncertainty, and highlight aspects that need further improvement. Data evaluation is a critical step of the conservation planning process, as data quality may influence the reliability of the analyses and the interpretation of the respective outcomes (Levin et al., 2014). However, the systematic evaluation of datasets presents several challenges, as various aspects that affect data quality are arbitrary (e.g., habitat definitions, geographic position, spatial/temporal extent) and hence suffer from intrinsic biases (Ciroth, 2009). Moreover, metadata are usually expressed in a qualitative manner or their documentation is insufficient. It is therefore difficult to extract a meaningful result regarding the overall data reliability, especially when a large amount of datasets is combined. One way to overcome this hurdle is the use of a pedigree matrix which transforms qualitative metadata into semi-quantitative indicators of data quality. This approach was originally proposed by Weidema and Wesnæes (1996) and was later tested by Issaris et al. (2012) on data used for ecological mapping.

Following the methods employed by the aforementioned studies, a modified pedigree matrix was applied to evaluate the reliability, completeness, spatiotemporal cohesion, and data acquisition methods of the datasets used for the mapping of the distribution of ecological features (Table 3). Each quality indicator was assessed based on five indicator-specific scoring criteria, ranking from 1 (high quality) to 5 (low quality). The "reliability" indicator relates to the data sources and the verification procedures used (e.g., species identification process) to obtain the data; the "completeness" indicator relates to the statistical properties of the data (the spatial and temporal representativity of samples); the "temporal relevance" indicator represents the year the data were obtained relative to the year of the data quality assessment; the "geographical relevance" refers to the level of accuracy of the obtained geographic positioning metadata. Additionally, the "data acquisition methods" indicator relates to the methods used to collect primary data (research focus and applied methodology). The scoring procedure was applied separately for distinct ecological features and the resulting values were graphically displayed using radar charts (Figure 5). Indicator scores were calculated using the weighted average of all data sources considered. 
TABLE 3 | Data quality evaluation based on a pedigree matrix adapted from Weidema and Wesnæs (1996) and Issaris et al. (2012).

\begin{tabular}{|c|c|c|c|c|c|}
\hline \multirow{2}{*}{$\begin{array}{l}\text { Data quality } \\
\text { indicator }\end{array}$} & \multicolumn{5}{|c|}{ Indicator criteria and scoring values } \\
\hline & 1 & 2 & 3 & 4 & 5 \\
\hline Reliability & Quantitative/measured data & $\begin{array}{l}\text { Data based on quantitative } \\
\text { assumptions and expert } \\
\text { judgment }\end{array}$ & $\begin{array}{l}\text { Data based on qualitative } \\
\text { observations made by } \\
\text { experts but verified by } \\
\text { supporting information (e.g., } \\
\text { geo-referenced, } \\
\text { photographic archives, } \\
\text { photo ID) }\end{array}$ & $\begin{array}{l}\text { Data based on qualitative } \\
\text { observations made by } \\
\text { non-experts but verified by } \\
\text { supporting information }\end{array}$ & $\begin{array}{l}\text { Unverified data with little } \\
\text { supporting information }\end{array}$ \\
\hline Completeness & $\begin{array}{l}\text { Data coverage is } \\
\text { representative for the entire } \\
\text { study area, over an } \\
\text { adequate time period to } \\
\text { even-out normal fluctuations }\end{array}$ & $\begin{array}{l}\text { Representative data from } \\
>50 \% \text { of the study area, } \\
\text { over an adequate time } \\
\text { period to even-out normal } \\
\text { fluctuations }\end{array}$ & $\begin{array}{l}\text { Representative data from } \\
\text { only some sites ( }<50 \%) \text { of } \\
\text { the study area, OR }>50 \% \text { of } \\
\text { the study area but from } \\
\text { shorter time periods }\end{array}$ & $\begin{array}{l}\text { Representative data from } \\
\text { only one OR from few sites } \\
\text { of the study area but from } \\
\text { shorter time periods }\end{array}$ & $\begin{array}{l}\text { Representativeness } \\
\text { unknown or data from a } \\
\text { small number of sites } \\
\text { AND/OR from shorter time } \\
\text { periods }\end{array}$ \\
\hline $\begin{array}{l}\text { Temporal } \\
\text { relevance }\end{array}$ & $\begin{array}{l}\text { Data acquired }<3 \text { years to } \\
\text { the year of study. In case of } \\
\text { long-term monitoring, this } \\
\text { corresponds to the last year } \\
\text { of data acquisition }\end{array}$ & $\begin{array}{l}3-6 \text { years to the year of } \\
\text { study }\end{array}$ & $\begin{array}{l}6-10 \text { years to the year of } \\
\text { study }\end{array}$ & $\begin{array}{l}10-15 \text { years to the year of } \\
\text { study }\end{array}$ & $\begin{array}{l}>15 \text { years to the year of } \\
\text { study, or unknown }\end{array}$ \\
\hline $\begin{array}{l}\text { Geographical } \\
\text { relevance }\end{array}$ & Geo-referenced data & $\begin{array}{l}\text { In situ approximate GPS } \\
\text { coordinates (e.g., } \\
\text { start-end of survey } \\
\text { positions) }\end{array}$ & $\begin{array}{l}\text { Ex situ approximate GPS } \\
\text { coordinates (e.g., points on } \\
\text { a map) }\end{array}$ & $\begin{array}{l}\text { Descriptive spatial } \\
\text { information based on } \\
\text { selected terrestrial points }\end{array}$ & $\begin{array}{l}\text { Descriptive spatial } \\
\text { information on wider area }\end{array}$ \\
\hline $\begin{array}{l}\text { Data } \\
\text { acquisition } \\
\text { methods }\end{array}$ & $\begin{array}{l}\text { Data from targeted research } \\
\text { (i.e. focusing on one or } \\
\text { more of the specific } \\
\text { ecological features -species } \\
\text { or habitats- addressed } \\
\text { through this case study), } \\
\text { using standard } \\
\text { methodology }\end{array}$ & $\begin{array}{l}\text { Data from targeted } \\
\text { research, conducted by } \\
\text { different methodologies } \\
\text { (e.g., optical, acoustic, } \\
\text { fishing methods) }\end{array}$ & $\begin{array}{l}\text { Data from wider-scope } \\
\text { research, conducted using } \\
\text { standard methodology }\end{array}$ & $\begin{array}{l}\text { Data from wider-scope } \\
\text { research, conducted using } \\
\text { different methodologies }\end{array}$ & $\begin{array}{l}\text { Data acquired by experts or } \\
\text { non-experts, using no } \\
\text { particular methodology }\end{array}$ \\
\hline
\end{tabular}

\section{RESULTS}

A summary of the main results on the distribution patterns of ecological features is provided below, alongside illustrative maps (Figures 2, 3), the main outcomes of the data evaluation procedure (Table 4, Figure 5), as well as estimates regarding the proportion of ecological features that is represented within existing designated areas for conservation (Tables 1, 2). Detailed maps of the geographic distribution per ecological feature and analytical lists of the data sources used are provided in the Supplementary Files 2, 3, and 4.

\section{Coastal Lagoons (Figure 2A)}

Coastal lagoons are represented by 77 point data. Most of them are found along the coastlines of mainland Greece (67\%), while the remaining are scattered around several insular areas.

\section{Marine Habitats of the Infralittoral Zone $(<30 \mathrm{~m})$-Seagrass Beds, Soft Substrates, and Hard Substrates (Figure 2A)}

Resulting information includes a total area cover of $2,750 \mathrm{~km}^{2}$ ( $1.3 \%$ of entire study area) for soft substrates, $1,590 \mathrm{~km}^{2}(0.7 \%)$ for seagrass beds, and $164 \mathrm{~km}^{2}$ (0.08\%) for rocky substrates. Data quality was high for the seagrass beds and soft substrate habitats, as the spatial resolution of satellite images was considered to be sufficient for the visual identification of these habitat types. On the contrary, complementary experts' judgment and groundtruth sampling indicated that the mapping of hard substrates is, as yet, incomplete.

\section{Marine Caves (Figure 2B)}

A total of 622 marine caves have been recorded within the study area. Most of the point data (85\%) correspond to semisubmerged caves, the majority of which (70\%) are located in the island-dominated S Aegean region, while only 7\% stands for marine caves found along the mainland coastline. According to the results, marine caves appear to be more abundant in the Cyclades, the southeastern Aegean, and the Northern Sporades island complexes, where limestone coasts prevail. Data quality for this habitat is overall high, mainly due to the large amount of information regarding semi-submerged caves.

\section{Submarine Structures Made by Leaking Gases-SSLG (Figure 2B)}

The presently known distribution of this habitat is restricted to four points, which are located nearby volcanic 

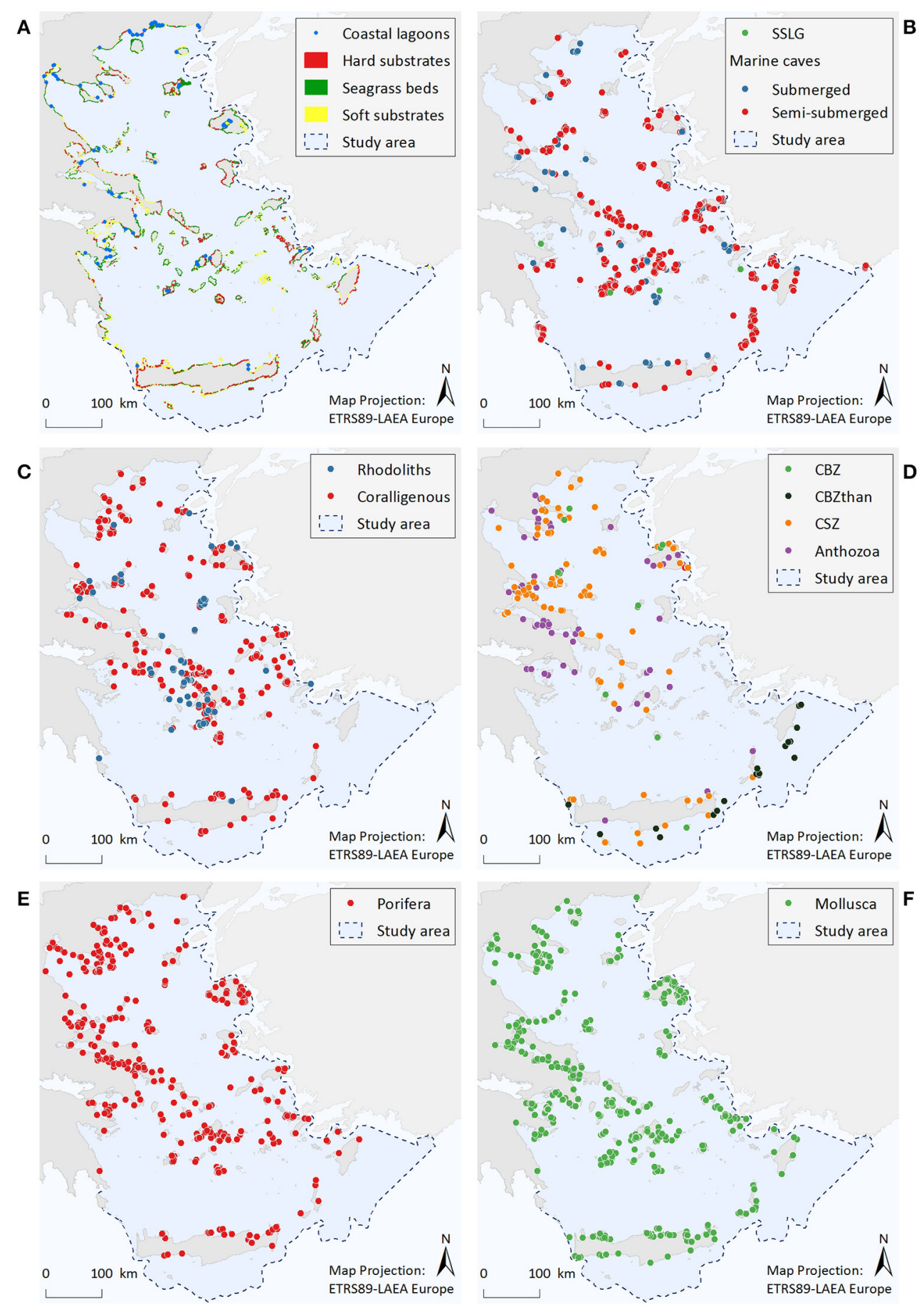

FIGURE 2 | Illustrative maps depicting the distribution of (A) Coastal lagoons, hard substrates, seagrass beds, and soft substrates, (B) Submarine structures made by leaking gases (SSLG) and marine caves, (C) Rhodolith beds and coralligenous formations, (D) Corals of the bathyal zone (CBZ), Corals of the bathyal zone thanatocoenoses (CBZthan), Corals of the sublittoral zone (CSZ), and Anthozoa, (E) Porifera, (F) Mollusca.

hotspots along the Aegean volcanic arc. Taking into account the high volcanic and tectonic activity of the wider Aegean region, this dataset cannot be considered as complete.

\section{Rhodolith Beds (Figure 2C)}

The distribution of rhodolith beds is described by 62 point data and a total polygon area cover of $72 \mathrm{~km}^{2}$. Available data refer to rhodolith beds mainly found in waters deeper than $40 \mathrm{~m}$, with 

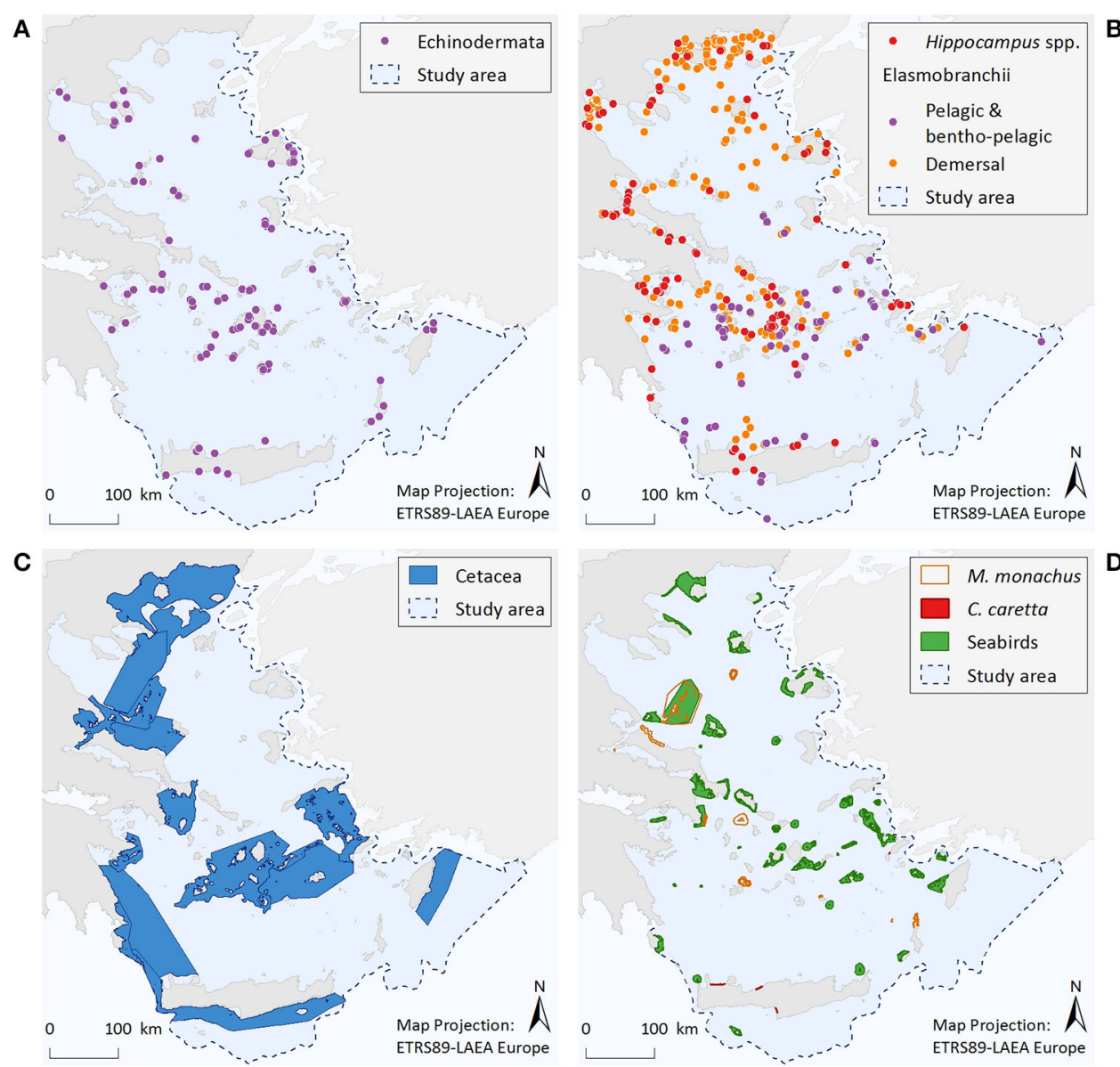

FIGURE 3 | Illustrative maps depicting the distribution of (A) Echinodermata, (B) Hippocampus spp. and Elasmobranchii, as well as important areas for (C) Cetacea, and (D) Monachus monachus, Caretta caretta, and seabirds.

the Cyclades plateau being the most extensively studied area. In the rest of the Aegean, there are important data gaps, while the majority of records (57\%) refer to data obtained more than 15 years ago.

\section{Coralligenous Formations (Figure 2C)}

Available information consists of 326 point data and a total polygon area cover of $71 \mathrm{~km}^{2}$. Out of all available records, $49 \%$ refer to the minute reefs morphotype (coralligenous platforms), $30 \%$ refer to coralligenous of the littoral rock, whereas the morphotype was unspecified for $21 \%$ of the records (i.e., no relevant information was provided in the data sources). Most records of coralligenous platforms are situated in the S Aegean, $76 \%$ of which relate to research conducted at the Cyclades plateau, reflecting an increased research effort focusing specifically on this area (see also Figures S2.8a,b in Supplementary File 2). At the specific area, the minute reefs morphotype has shown high spatial density at depths between 80 and $110 \mathrm{~m}$. On the other hand, records of coralligenous formations of the littoral rock are more numerous in the $\mathrm{N}$ Aegean Sea (65\%), where they are more densely distributed along the coasts of Chalkidiki, Pelio, and the Northern Sporades islands. In the S Aegean, this coralligenous morphotype is mainly scattered along the coasts of the insular areas. Data quality is overall low in terms of completeness, as dedicated research for both morphotypes is generally lacking in most parts of the study area.

\section{Protected Anthozoa, Corals of the Sublittoral Zone, and Corals of the Bathyal Zone (Figure 2D)}

The distribution of corals of the sublittoral zone is described by a total of 169 point data. Most observations come from the $\mathrm{N}$ Aegean (84\%), and particularly from the Chalkidiki and Pelio peninsulas, as well as from the Northern Sporades and Evia islands. Of the protected Anthozoa dataset, the scleractinian coral C. caespitosa (143 points) also presents an overall northwest to southeast decreasing trend, showing a higher frequency of records in the areas of the Evoikos Gulf (25\%), Chalkidiki Peninsula (20\%), Lesvos Island (13\%), and Pelio Peninsula (13\%). On the other hand, the sparse records of the other protected Anthozoa species 
TABLE 4 | Scoring values (weighted averages) of individual ecological features per data quality indicator.

\begin{tabular}{|c|c|c|c|c|c|}
\hline & Reliability & Completeness & Temporal relevance & Geographical relevance & Data acquisition method \\
\hline \multicolumn{6}{|l|}{ PROTECTED SPECIES } \\
\hline Porifera & 2.1 & 3.4 & 2.4 & 2.5 & 2.9 \\
\hline Anthozoa-Cladocora caespitosa & 2.6 & 4.0 & 1.7 & 2.5 & 3.3 \\
\hline Anthozoa-Other protected Anthozoa & 1.0 & 3.0 & 3.6 & 2.7 & 1.0 \\
\hline Mollusca & 3.0 & 4.4 & 2.1 & 2.7 & 4.0 \\
\hline Echinodermata & 3.3 & 4.3 & 1.7 & 2.5 & 4.0 \\
\hline Hippocampus spp. & 1.8 & 3.5 & 2.7 & 3.0 & 3.5 \\
\hline Elasmobranchii (pelagic and bentho-pelagic) & 1.0 & 3.0 & 4.0 & 1.0 & 1.0 \\
\hline Elasmobranchii (benthic) & 1.0 & 3.0 & 4.0 & 3.0 & 3.0 \\
\hline Caretta caretta & 1.0 & 1.0 & 1.0 & 3.0 & 2.0 \\
\hline Cetacea & 2.0 & 3.0 & 1.0 & 1.0 & 2.0 \\
\hline Monachus monachus & 1.0 & 3.0 & 1.0 & 1.0 & 1.0 \\
\hline Seabirds & 1.0 & 1.0 & 2.0 & 1.0 & 1.0 \\
\hline \multicolumn{6}{|l|}{ KEY HABITATS } \\
\hline Coastal lagoons & 2.0 & 2.0 & 1.0 & 1.0 & 1.0 \\
\hline Soft substrates & 1.0 & 2.0 & 1.0 & 1.0 & 1.0 \\
\hline Seagrass beds & 1.0 & 2.0 & 1.0 & 1.0 & 1.0 \\
\hline Hard substrates & 1.0 & 3.0 & 1.0 & 1.0 & 1.0 \\
\hline Marine caves & 1.3 & 1.6 & 1.0 & 1.8 & 1.4 \\
\hline Submarine structures made by leaking gases & 3.0 & 4.0 & 2.0 & 3.0 & 3.0 \\
\hline \multicolumn{6}{|c|}{ OTHER VULNERABLE ECOLOGICAL FEATURES } \\
\hline Rhodolith beds & 2.3 & 4.2 & 3.8 & 1.5 & 2.0 \\
\hline Coralligenous formations & 2.1 & 3.9 & 3.0 & 1.7 & 3.0 \\
\hline Corals of the sublittoral zone & 1.6 & 3.7 & 3.2 & 2.6 & 2.8 \\
\hline Corals of the bathyal zone & 2.2 & 5.0 & 4.6 & 4.0 & 3.4 \\
\hline All data & 2.2 & 3.2 & 2.0 & 2.3 & 3.2 \\
\hline
\end{tabular}

Scores are the weighted average of all data sources considered per ecological feature.

(namely Antipatharia spp., Callogorgia verticillata, and Savalia savaglia) and the corals of the bathyal zone do not reveal any particular distribution trend. However, the deepcoral thanatocoenoses ( $N=29$ points) located southwards of Crete, Karpathos and Rhodes islands, which overall coincide with live specimens of other anthozoan species, are indicative of a potentially important area for deepwater coral communities. Information gaps regarding all the aforementioned ecological features appear to exist in several parts of the Aegean, as reflected by the high scores of the completeness indicator.

\section{Porifera (Figure 2E)}

The geographic distribution of the nine sponge taxa is depicted by 964 point data. Most records refer to the distribution of Aplysina spp. (33\%), Sarcotragus foetidus (30\%), and Axinella cannabina (18\%). The remaining species have less than $10 \%$ of the total records each, the lowest being $P$. massiliana with only two records and $S$. pipetta with one record. Overall, the number of point data was greater in the N Aegean Sea ( $60 \%)$ compared to the S Aegean, while records in insular areas $(57 \%)$ and mainland (43\%) had approximately the same relative frequency of occurrence.

\section{Mollusca (Figure 2F)}

The geographic distribution of the nine Mollusca species is represented by 904 point data, $51 \%$ of which corresponds to
P. nobilis. The large gastropods Charonia variegata and Tonna galea are linked to 12 and $11 \%$ of the records, respectively, Lithophaga lithophaga to $10 \%$, while the remaining species are below $10 \%$ each. The least observed species is Mitra zonata, with only two records. The frequency of records for C. variegata, T. galea, E. spurca, and Zonaria pyrum shows a decrease from northern to southern Aegean areas; L. lithophaga displays a reverse trend; while for Luria lurida, Pholas dactylus, and M. zonata results are inconclusive due to limited records.

\section{Echinodermata (Figure 3A)}

Information regarding the two protected Echinodermata species corresponds to a total of 179 point data; specifically, C. longispinus has 88 records and O. ophidianus 91. Centrostephanus longispinus records display an increasing trend from $\mathrm{N}$ to $\mathrm{S}$ Aegean areas, with $73 \%$ of the point data coming from the south. Records of $O$. ophidianus are more equally distributed between the $\mathrm{N}(44 \%)$ and $\mathrm{S}$ (56\%) Aegean areas. For both species frequency of records originating from the mainland is generally low compared to the insular coasts ( 8 and $20 \%$, for C. longispinus and O. ophidianus, respectively). Information regarding the distribution of protected Echinodermata presents significant knowledge gaps, as reflected by the low number of records and the fact that most information comes from anecdotal 
observations (acquired through interviews) and not systematic sampling.

\section{Osteichthyes-Hippocampus spp. (Figure 3B)}

The distribution of Hippocampus species is described by 137 point data in total, $56 \%$ of which correspond to H. hippocampus, $22 \%$ to $H$. guttulatus, and $22 \%$ to Hippocampus specimens that were not identified at the species level. Records of both species occur throughout the Aegean Sea; however, given the limited information currently available, no spatial patterns can be identified.

\section{Pelagic and Bentho-Pelagic Elasmobranchii (Figure 3B)}

Total records of large pelagic or bentho-pelagic sharks amount to 90 point data. These refer to $H$. perlo (67\%), G. galeus (29\%), and I. oxyrinchus (4\%). Records of sharks can be found throughout the Aegean Sea. However, their density is higher at the southern insular areas, especially around the Cyclades and Dodecanese island complexes. Information gaps can be observed along the southeastern coasts of Crete and at several eastern Aegean islands, and mainly reflect differences in fisheries-dependent scientific effort.

\section{Benthic Elasmobranchii (Figure 3B)}

The dataset includes 439 point data. The rays Gymnura altavela and Mobula mobular comprise $7 \%$ of the data points, the skates Dipturus batis, Leucoraja circularis, L. melitensis, and Rostroraja alba 24\%, the guitar fish Rhinobatos rhinobatos $1 \%$, the torpedo ray Tetronarce nobiliana $45 \%$, and the demersal sharks Hexanchus griseus, Oxynotus centrina, Squatina aculeata, S. oculata, and S. squatina $23 \%$. Records of these species come from most parts of the Aegean Sea, although the density of records is higher in certain areas, such as, the Thracian coasts, the Thermaikos Gulf, and the Cyclades Archipelago.

\section{Cetacea (Figure 3C)}

Based on the entire distribution range of the seven cetacean species considered, six broad and interlinked important areas have been identified, consisting of both coastal and offshore pelagic waters. These areas represent density and residency hotspots, and/or important ecological corridors connecting distant population units.

\section{The Mediterranean Monk Seal Monachus monachus (Figure 3D)}

Within the Aegean Sea, several important monk seal pupping areas have been identified to date. The Northern Sporades Islands (including the National Marine Park of Alonissos Northern Sporades) is estimated to host a population of more than 50 individuals. The Kimolos-Polyaigos island complex (SW Cyclades) has a breeding colony of 50 animals. The areas of $\mathrm{N}$ Karpathos and Saria (S Dodecanese Islands) have a population of $\sim 25$ individuals, while a breeding colony of $\sim 60$ individuals has been discovered at Gyaros Island (N Cyclades). More recent field research conducted by MOm has revealed the existence of additional sites with constant pupping activity at the northern parts of Evia island, as well as at the islands of Agios Efstratios (N Aegean), Anafi (SE Cyclades), and Makronissos (SW Aegean, close to Attica coasts). Several other less investigated sites may also be of high importance for this pinniped (Figure 3D). Since the initiation of the systematic monitoring efforts of $M$. monachus in 1991, 40\% of the entire Greek coastline has been surveyed; as yet, there are still large areas that remain unexplored which may host important breeding sites for this species.

\section{The Loggerhead Sea Turtle Caretta caretta (Figure 3D)}

Four important nesting sites for the loggerhead sea turtle have been identified within the Aegean Sea; three at the island of Crete, and one at Kos Island.

\section{Seabirds (Figure 3D)}

Important areas for marine birds sum up to 42 sites distributed throughout the Aegean Sea. These areas are highly variable in size, and have a strictly marine character (i.e., their boundaries are delimited by the coastline and do not include inland stretches). As dictated by the species distribution and behavioral patterns, selected areas represent four types of sites: seaward extensions to breeding colonies, non-breeding (coastal) concentrations, migratory bottlenecks, and areas for pelagic species.

\section{Occurrence of Ecological Features in Areas of Protection Status}

Within the Greek territorial waters of the Aegean Sea there are currently seven National Parks and 186 Natura 2000 sites encompassing marine coastal waters (Figure 4A). Out of the whole study area $\left(213,167.6 \mathrm{~km}^{2} / 29,628\right.$ grid cells), the total surface area of designated waters for protection is $4,955.8 \mathrm{~km}^{2}$ (2.3\%). This corresponds to 1.1 and $2.3 \%$ of the study area as National Parks and Natura 2000 sites respectively, but with an overlapping area of $2,257.8 \mathrm{~km}^{2}(1.1 \%)$. The proportion of the different ecological features found within existing National Parks and/or Natura 2000 sites is listed in Tables 1, 2. Specifically, only three ecological features (the species M. monachus, G. altavela, and C. caretta) are represented by more than $60 \%$ of their total estimated distribution within National Parks or Natura 2000 sites, 24 by $20-60 \%, 22$ by $<20 \%$ (but not zero), while 19 ecological features have not been recorded in designated areas.

When the total number of ecological features per grid cell is considered (Figure 4B), it becomes evident that cells with a relative high number of ecological features ( $>5$ features) are most commonly found in coastal waters, possibly reflecting an increased sampling effort in the shallower parts of study area, and especially around the Northern Sporades, the Cyclades and the Dodecanese island complexes, as well as along the Thracian coasts. Moreover, small pockets of high feature diversity $(>10$ features) are scattered around different parts of the Aegean Sea. These high diversity locations correspond to 193 cells, $71 \%$ of which falls within Natura 2000 sites, 30\% is found in locations where National Parks and Natura 2000 sites coincide, while 29\% is located in areas bearing no protection status. 

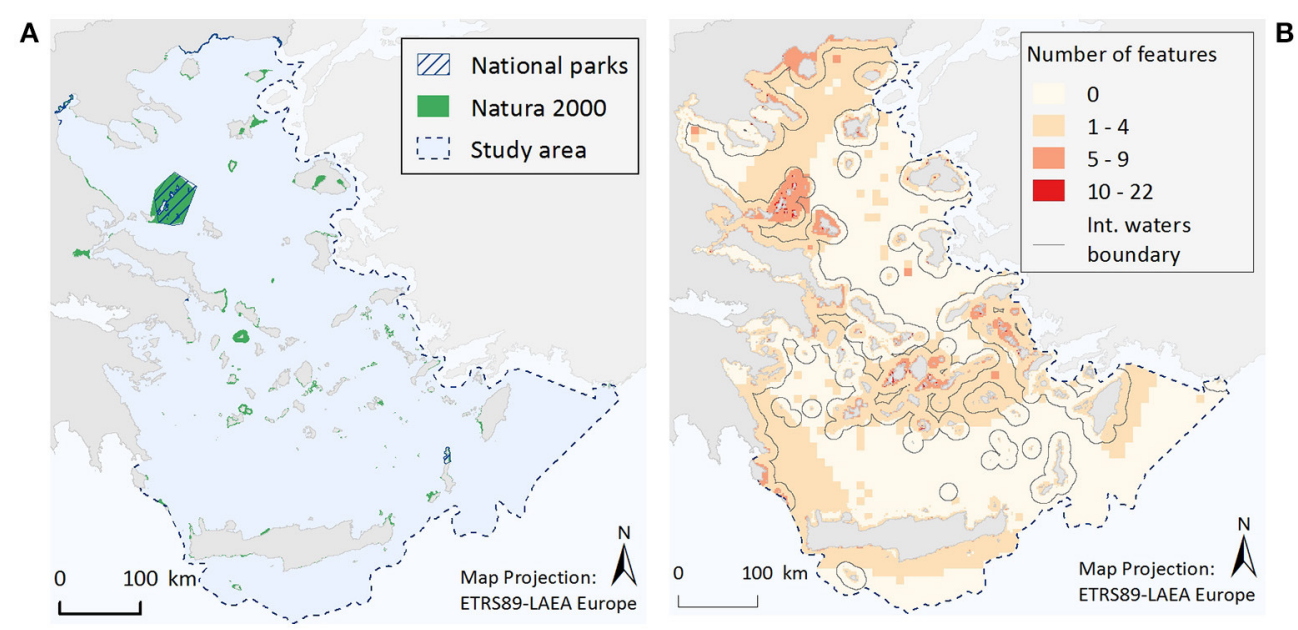

FIGURE 4 | Illustrative maps depicting (A) National Parks and Natura 2000 sites, and (B) the number of ecological features found in different parts of the study area.

\section{Data Quality Scores}

The results of the data quality evaluation, based on the five qualitative indicators, are presented in Table 4 and Figure 5. As a general rule, low-scoring indicators represent good data quality, while high-scoring indicators refer to weak points that should be taken into account during any future decision-making process. The weakest indicator of the overall dataset is "completeness," showing that there are still several areas of the Aegean Sea that remain understudied, and that the distribution of certain ecological features needs further investigation. On the other hand, most of the available data are sufficient in terms of "reliability," "temporal relevance," and "geographical relevance."

The ecological features with the highest-scoring valuesand hence highest uncertainty-were the taxa of Porifera, Mollusca, and Echinodermata, due to the fact that their datasets were largely based on information provided by interviews. Specifically, these features ranked low in terms of "reliability" (i.e., information provided primarily by non-experts), quality of the methods used to acquire the data (i.e., circumstantial visual observations and not systematic methodologies), and geospatial precision (i.e., descriptive spatial information rather than geo-referenced). Additionally, several ecological features that generally occur in waters deeper than $40 \mathrm{~m}$, such as, rhodolith beds, coralligenous formations, corals of the sublittoral and bathyal zones, and submarine structures made by leaking gases, as well as most of the protected anthozoan species, presented low quality with respect to several indicators, particularly those referring to "completeness," "data acquisition methods," and the "temporal relevance" of data. These values highlight the need for more dedicated scientific research that will specifically focus on these features.

\section{DISCUSSION}

This study is the first to assess, at a large scale, the spatial distribution of key marine habitats and species in the Aegean ecoregion. A wide range of data sources and methodological approaches was utilized to address the versatility of ecological features and update the presently available scientific records. Moreover, the systematic assessment of data quality provided useful insights regarding the credibility of the obtained information, allowed the detection of potential data deficiencies or inaccuracies, and helped identify information gaps that need further investigation. Such quality assessment is also useful in weighing the different lines of evidence when the data is to be used within integrated assessment schemes, as is common in ecosystem-based management approaches.

With respect to marine habitats of the infralittoral zone $(<30 \mathrm{~m})$, the analysis of satellite images allowed for a detailed mapping of seagrasses and soft substrates, and to a rough delineation of hard substrates. These three broad habitat categories typically occur in an alternating manner throughout the coastal waters of the Aegean Sea. The medium spatial resolution images used were sufficient for the identification of seagrass beds and soft substrates (covering an area of 1,590 and $2,750 \mathrm{~km}^{2}$, respectively). Notably, the estimated cover of seagrass beds provided herein, as well as the percentage of coastline investigated, is comparably higher than the respective estimate of Telesca et al. (2015). The latter study reported a total area cover of $P$. oceanica beds of $449.39 \mathrm{~km}^{2}$, a value that corresponds to only $8 \%$ of the surveyed Greek coastline, based on data available at the time. Hence, the current map represents the most complete depiction of seagrasses in the Aegean Sea to date. On the contrary, finer resolution satellite images and groundtruth sampling would enable a more realistic depiction of hard substrates. Many rocky outcrops are smaller than the spatial resolution of the images, are commonly fragmented and scattered along different depths, or frequently co-occur with other habitats (such as, $P$. oceanica beds) which overshadow their presence and their actual spatial extent. Moreover, vertically inclined walls and rocky reefs found in areas of high turbidity or sedimentation are almost impossible to detect in two-dimensional aerial or satellite images. Taking into account the geomorphological profile of the study area, the resulting area cover of this habitat category 


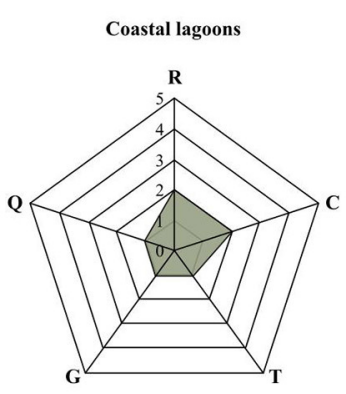

Rhodolith beds

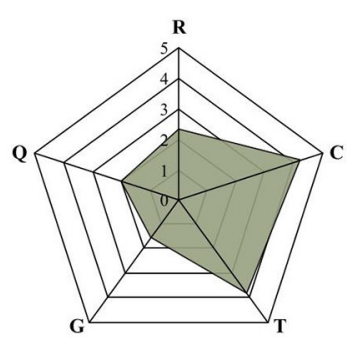

Porifera

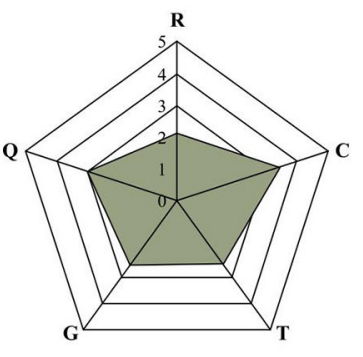

Echinodermata

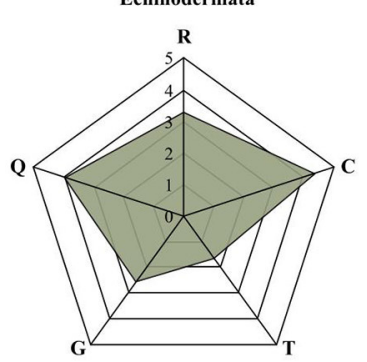

Caretta caretta

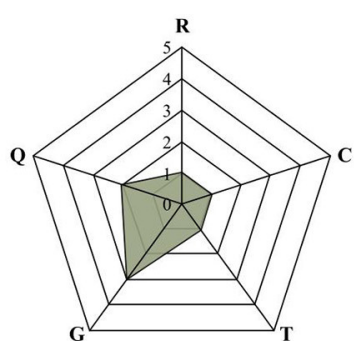

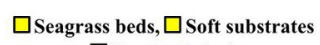

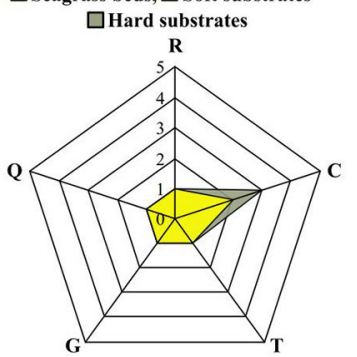

Coralligenous formations

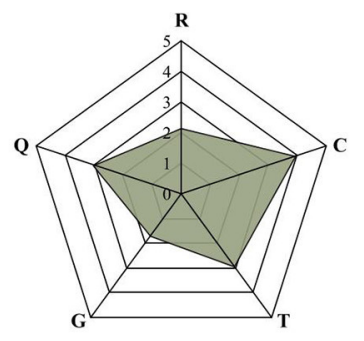

Anthozoa - Cladocora caespitosa
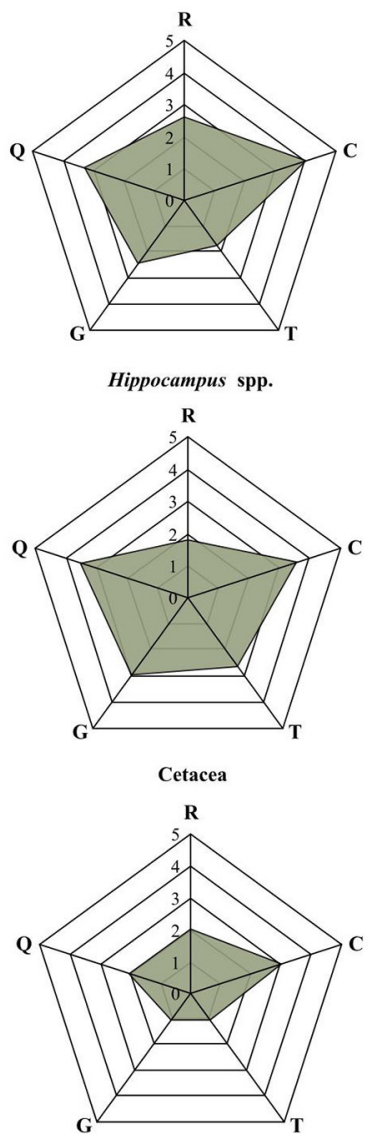

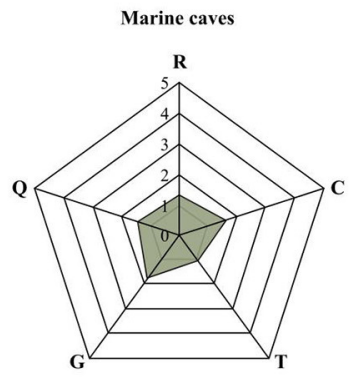

Corals of the sublittoral zone (CSZ)

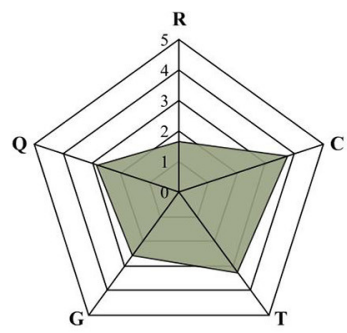

Anthozoa - Other protected Anthozoa

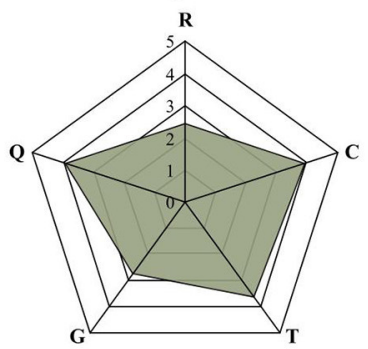

Elasmobranchii (pelagic \& bentho-pelagic)

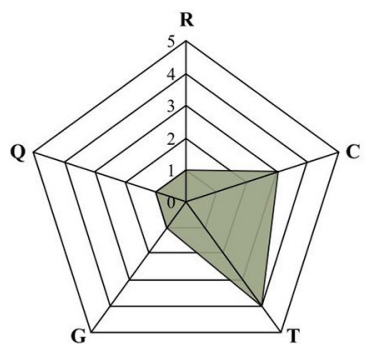

Monachus monachus

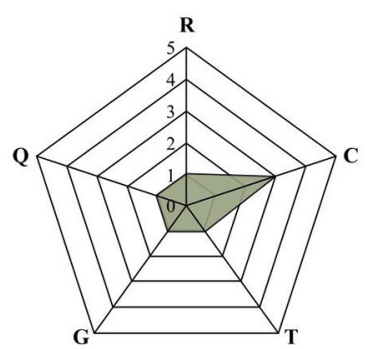

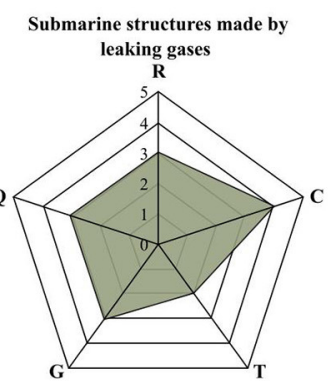

Corals of the bathyal zone (CBZ)
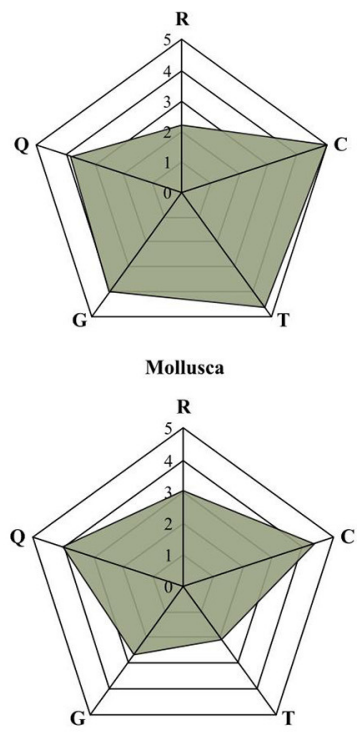

Elasmobranchii (benthic)

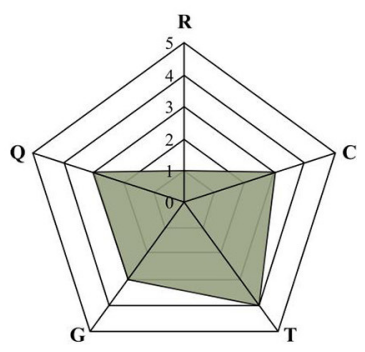

Seabirds

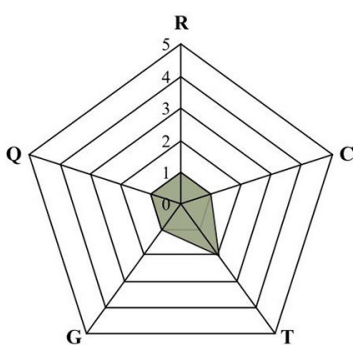

FIGURE 5 | Radar charts illustrating the data evaluation scores per group of ecological features, based on the five data quality indicators of the pedigree matrix. R, Reliability indicator; C, Completeness indicator; T, Temporal relevance indicator; G, Geographical relevance indicator; Q, Data acquisition methods indicator. 
$\left(164 \mathrm{~km}^{2}\right)$ is deemed as incomplete, although reliable in terms of data quality. Future research should focus on addressing this knowledge gap by using higher spatial resolution satellite images (e.g., Sentinel-2) and by creating a robust open-access database for further validation and reference; this data repository should also incorporate information on the geomorphological characteristics, position, and bathymetric extent of rocky areas.

Complementary to the data provided by Giakoumi et al. (2013), the current cave dataset provides information on 120 additional cave locations ( $20 \%$ increase), summing up to a total of 622 caves that are scattered throughout the study area. Given the complexity of the Aegean coastline and the ongoing geodynamic processes, it is almost impossible to provide an exact number of marine caves existing in this ecoregion, but the actual number is assumed to be much higher. Thus far, the majority of records (>85\%) corresponds to semi-submerged caves, which are easier to spot and access by scientists and recreational divers. However, the increasing interest for the monitoring and protection of this habitat type (UNEP-MAP-RAC/SPA, 2015a, 2017; Gerovasileiou et al., 2016), coupled with the new trends of recreational SCUBA diving, including cave and deep diving, are expected to further raise the number of existing records, especially those of the entirely submerged caves.

For the ecological features that are found in the circalittoral $(>40 \mathrm{~m})$ and bathyal zones $(>200 \mathrm{~m})$, the majority of information scored low in completeness, temporal relevance, and data acquisition methods, suggesting that more dedicated research effort is needed in space and time to adequately map and assess the biotic components of these hard to approach depth zones. Rhodolith beds, coralligenous formations, and corals of the sublittoral zone are widely recognized as characteristic features of the Mediterranean seascape (Giakoumi et al., 2013; Martin et al., 2014) which are severely affected by numerous human-induced pressures, such as fisheries, marine litter and climate change (e.g., Barberá et al., 2003; Salomidi et al., 2012; Bo et al., 2014; Angiolillo et al., 2015; Basso et al., 2016a). Yet again, their wide bathymetric range poses several obstacles to their accurate definition and assessment (Salomidi et al., 2012; Basso et al., 2016a). Considering these difficulties, the current distribution maps provide valuable information regarding their presence in certain areas of the Aegean ecoregion. Additional focused surveys, utilizing a combination of advanced marine remote sensing techniques (e.g., multibeam echosounders, side scan sonars; Zapata-Ramírez et al., 2013), and well-designed ground truth sampling (i.e., through the use of SCUBA diving, drop cameras, and ROVS) are needed to obtain more accurate and representative estimates of their current distribution. Dedicated deep water exploratory surveys are also expected to enhance our knowledge regarding the presence of the-even more neglected-coral communities of the bathyal zone, as well as of the several protected anthozoans that are typically found in the circalittoral zone, and the submarine structures made by leaking gases.

With regards to protected species, our results suggest that systematic quantitative information of their spatial distribution is greatly missing for the majority of taxonomic groups. Such information is only available for seabirds, cetaceans, monk seals, and sea turtles, owing to the committed work conducted by the respective environmental non-governmental organizations (e.g., Frantzis, 2009; Karamanlidis et al., 2015). However, despite the large amount of existing scientific evidence, no specific management measures have been implemented so far to enhance the conservation of these species. The only exception is the National Marine Park of Alonissos Northern Sporades, which was established for the protection of the Mediterranean monk seal. Still, important populations of this pinniped remain unprotected in many areas of the Aegean (Notarbartolo di Sciara et al., 2009), while declining trends have been observed for several other charismatic, commercial, and protected species, including bath sponges, the red coral, edible bivalves, and elasmobranchs (Voultsiadou et al., 2013).

Information regarding the distribution of ichthyofauna is mostly based on fisheries-dependent surveys. Hence, the spatial patterns of the various elasmobranch and seahorse species largely reflect the spatiotemporal characteristics of fishing effort, rather than the actual extent of the species' current distribution range. Fisheries-independent surveys and the use of advanced tools for remote tracking (Letessier et al., 2017) could greatly improve current knowledge regarding the distribution trends and population status of these species, and provide useful insights regarding the existence of important breeding or nursery grounds.

Further research is also needed to assess the current status of the various benthic species considered herein. Most of the data regarding the geographic distribution of Porifera, Mollusca, Echinodermata, and Anthozoa come from incidental observations, made by experts and non-experts alike, following no systematic methodology. All of the alleged strictly protected molluscan species continue to be commercially exploited throughout the Aegean (Katsanevakis et al., 2008, 2011a), whereas systematic studies assessing their conservation status need to be updated. Many sponges (and other sessile invertebrates) often lack conspicuous external morphological characteristics that would allow easy and reliable identification in situ (Van Soest et al., 2012). Thus, additional criteria, such as genetic divergence, should also be considered (Boury-Esnault et al., 2013), and new assessments are required to elucidate the taxonomic status and distribution range of several species with unresolved or controversial taxonomy (see Cook and Bergquist, 2002; Heim et al., 2007).

It is important to note that the input of non-experts, volunteers, and recreational divers has greatly contributed to the data acquisition process, not just of the present study but also in the framework of long-term monitoring projects (e.g., the Hellenic Rescue and Information Network-RINT for the Mediterranean monk seal; the National Rescue Network for sea turtles). Complementary to scientific research, the production of well-informed and illustrated identification guides, and the strengthening of observatory networks, will foster the acquisition of more reliable information from both expert scientists and nonexpert naturalists (Costello et al., 2010). Once dealt with in a systematic manner (standardized and validated), this source of information can greatly enhance our knowledge on the past and 
present distribution patterns of key marine habitats and species. Citizen science is receiving growing attention as an effective tool to collect ecological information at large spatial scales (Bonney et al., 2009; Silvertown, 2009) and can be further utilized to update and improve the present dataset.

Overall, the existing conservation measures in the study area appear to be insufficient. Only $2.3 \%$ of the entire study area corresponds to waters that have been designated as National Parks or as Natura 2000 sites according to national and European legislation, while there is a high overlap among localities of different designation status. At the same time, only a small fraction of the ecological features considered is sufficiently represented within designated areas. The rather arbitrary criteria recommended by the European Commission guidelines for the selection of marine Natura 2000 sites (i.e., $20-60 \%$ of estimated distribution range for non-priority habitats or species, and $\geq 60 \%$ of priority habitats or species; ETC/BD, 2010) are only partly met for 27 ecological features, including two priority species, while 19 ecological features are never found within designated areas. Even more so, of all the designated areas, only a handful has a fully functional MPA status, i.e., following specific legal, administrative, and operational guidelines. Most of the designated areas have no legally binding framework or management plan, and there is an overall lack of effective surveillance and monitoring efforts.

The comprehensive data inventory presented in this study establishes a baseline for the development of scientifically sound spatial conservation plans that will safeguard the biodiversity of the region. Future steps should aim to improve the current maritime management regime and enhance conservation efforts by combining this ecological information with equivalent socioeconomic data (i.e., distribution maps of human activities, ongoing pressures, and existing spatial management measures) through a systematic spatial planning procedure. This will allow the design of a connected, adequate, representative, and efficient MPA network for the conservation of marine biodiversity in the Aegean Sea. Newly acquired data, along with information on the ecological status of distinct populations and habitats (including the associated habitat communities) can then be incorporated through adaptive management, in order to update the management measures within each protection zone, and readjust the spatial attributes of MPAs (e.g., configuration and size) where/when necessary. The spatial information presented herein may further be used as a starting point for the implementation of the ecosystem-based Integrated Monitoring and Assessment Program (UNEP/MAP, 2009), which was recently adopted by the Contracting Parties of the Barcelona Convention (2016). Species occurrence data may also be incorporated into global species databases, online repositories, and ongoing initiatives focusing on the cataloging and sustainable management of biodiversity (e.g., Bailly et al.,

\section{REFERENCES}

Abdulla, A., Gomei, M., Maison, E., Piante, C. (2008). Status of Marine Protected Areas in the Mediterranean Sea. Malaga and WWF. France: IUCN.
2016), which is a common requirement for all signatories of the CBD.

At the same time, trans-boundary collaboration is necessary to achieve comprehensive and environmentally meaningful conservation planning for the entire Aegean ecoregion, as ecologically important areas extend beyond territorial waters. The role of international conventions and agreements along with joint research initiatives and scientific networks can be pivotal to this end (Giakoumi et al., 2012a; Levin et al., 2014). The expansion of EU policies and regulations, such as the Marine Strategy Framework Directive (MSFD) and the Natura 2000 network, outside the strict EU borders through the Barcelona Convention may further promote common baseline data and research practices. This way, the spatial scale of conservation efforts can be broadened, while integration and coordination can be enhanced both at a regional, sub-basin level, and at the Mediterranean level as a whole.

\section{AUTHOR CONTRIBUTIONS}

Conceived, designed and coordinated the project: SK. Compiled, organized, analyzed and interpreted the data: MSin. Geodatabase development and handling: NK. Construction of maps: NK and MSin. Satellite image analyses: KT. Fieldwork: MSin, SK, VGerov, TD, TH, KT, and EM. Contribution of data/materials/analytical tools: MSin, SK, NK, VGerov, TD, DD, PD, XD, AF, VGerak, SG, TH, YI, SGK, DDK, EM, VM, AM, DP, GP, MSal, KT, VT, and MZ. MSin prepared the first draft of the manuscript. All authors contributed to data analyses, interpretation, and drafting of the paper, and have read and approved the final manuscript.

\section{FUNDING}

This work was conducted in the framework of the MARISCA project (2015-2016; www.marisca.eu), co-funded by $85 \%$ by the EEA GRANTS, 2009-2014, and 15\% by the Public Investments Programme (PIP) of the Hellenic Republic.

\section{ACKNOWLEDGMENTS}

We are grateful to all observers, divers, and diving centers for providing valuable information and technical support during fieldwork; a full list of all contributors can be found in the Supplementary File 4.

\section{SUPPLEMENTARY MATERIAL}

The Supplementary Material for this article can be found online at: https://www.frontiersin.org/articles/10.3389/fmars. 2017.00347/full\#supplementary-material

Almpanidou, V., Schofield, G., Kallimanis, A. S., Türkozan, O., Hays, G. C. and Mazaris, A. D. (2016). Using climatic suitability thresholds to identify past, present and future population viability. Ecol. Indic. 71, 551-556. doi: 10.1016/j.ecolind.2016.07.038 
Anagnostou, C., Chronis, G., Sioulas, A., Karageorgis, A. P., and Tziavos, C. (2005). "Morphodynamics and changes of the coastlines of Hellas," in State of the Hellenic Marine Environment, eds E. Papathanassiou and A. Zenetos (Athens: Hellenic Centre for Marine Research Publications), 21-33.

Angiolillo, M., di Lorenzo, B., Farcomeni, A., Bo, M., Bavestrello, G., Santagelo, G., et al. (2015). Distribution and assessment of marine debris in the deep Tyrrhenian Sea (NW Mediterranean Sea, Italy). Mar. Pollut. Bull. 92, 147-159. doi: 10.1016/j.marpolbul.2014.12.044

Antoniadou, C., Voultsiadou, E., and Chintiroglou, C. (2006). Sublittoral megabenthos along cliffs of different profile (Aegean Sea, Eastern Mediterranean). Belg. J. Zool. 136, 69-79.

Baggini, C., Issaris, Y., Salomidi, M., and Hall-Spenser, J. M. (2015). Herbivore diversity improves benthic community resilience to ocean acidification. J. Exp. Mar. Biol. Ecol. 469, 98-104. doi: 10.1016/j.jembe.2015.04.019

Baggini, C., Salomidi, M., Voutsinas, E., Bray, L., Krasakopoulou, E., and HallSpencer, J. M. (2014). Seasonality affects macroalgal community response to increases in $\mathrm{pCO}_{2}$. PLoS ONE 9:e106520. doi: 10.1371/journal.pone.01 06520

Bailly, N., Gerovasileiou, V., Arvanitidis, C., and Legakis, A. (2016). Introduction to the Greek taxon information system (GTIS) in lifewatchgreece: the construction of the preliminary checklists of species of Greece. Biodivers. Data J. 4:e7959. doi: 10.3897/BDJ.4.e7959

Ballesteros, E. (2006). Mediterranean coralligenous assemblages: a synthesis of present knowledge. Oceanogr. Mar. Biol. Ann. Rev. 44, 123-195. doi: 10.1201/9781420006391.ch4

Barberá, C., Bordehore, C., Borg, J. A., Glemarec, M., Grall, J., Hall-Spencer, J. M., et al. (2003). Conservation and management of northeast Atlantic and Mediterranean maërl beds. Aquat. Conserv: Mar. Freshw. Ecosyst. 13, S65-S76. doi: 10.1002/aqc.569

Basso, D., Babbini, L., Kaleb, S., Bracchi, V., and Falace, A. (2016a). Monitoring deep Mediterranean rhodolith beds. Aquat. Conserv: Mar. Freshw. Ecosyst. 26, 549-561. doi: 10.1002/aqc. 2586

Basso, D., Babbini, L., Ramos-Esplá, A., and Salomidi, M. (2016b). "Mediterranean rhodolith beds" in Rhodolith/Maerl Beds: A Global Perspective, Vol. 15, eds R. Riosmena-Rodríguez, W. Nelson, and J. Aguirre (Switzerland: Springer International Publishing, Coastal Research Library), 281-298.

Bertrand, J. A., Gil de Sola, L, Papaconstantinou, C., Relini, G., and Souplet, A. (2000). "An international bottom trawl survey in the Mediterranean: the Medits program," in Proceedings of the Symposium on Demersal Resources in the Mediterranean, Vol. 26, eds J. A. Bertrand and G. Relini (Pisa: Ifremer) Actes de Colloques, 76-93.

Bo, M., Bava, S., Canese, S., Angiolillo, M., Cattaneo-Vietti, R., and Bavestrello. G. (2014). Fishing impact on deep Mediterranean rocky habitats as revealed by ROV investigation. Biol. Conserv. 171, 167-176. doi: 10.1016/j.biocon.2014.01.011

Bonney, R., Cooper, C. B., Dickinson, J., Kelling, S., Phillips, T., Rosenberg, K. V., et al. (2009). Citizen science: a developing tool for expanding science knowledge and scientific literacy. BioScience 59, 977-984. doi: 10.1525/bio.2009. 59.11 .9

Boudouresque, C. F. (2004). Marine biodiversity in the Mediterranean: status of species, populations and communities. Sci. Rep. Port-Cros Natl. Park Fr. 20, 97-146.

Boury-Esnault, N., Lavrov, D. V., Ruiz, C. A., and Pérez, T. (2013). The integrative taxonomic approach applied to porifera: a case study of the Homoscleromorpha. Integr. Comp. Biol. 53, 416-427. doi: 10.1093/icb/ ict042

Carrier, J. C., Musick, J. A., Heithaus, M. R. (eds.) (2004). Biology of Sharks and their Relatives, New York, NY: CRC Marine Biology Series.

Casale P., and Margaritoulis, D. (eds.). (2010). Sea Turtles in the Mediterranean: Distribution, Threats and Conservation Priorities. Gland: IUCN.

Ciroth, A. (2009). Cost data quality considerations for eco-efficiency measures. Ecol. Econ. 68, 1583-1590. doi: 10.1016/j.ecolecon.2008. 08.005

Coll, M., Piroddi, C., Albouy, C., Ben Rais Lasram, F., Cheung, W. W. L., Christensen, V., et al. (2011). The Mediterranean Sea under siege: spatial overlap between marine biodiversity, cumulative threats and marine reserves. Global Ecol. Biogeogr. 21, 465-480. doi: 10.1111/j.1466-8238.2011. 00697.x

Coll, M., Piroddi, C., Steenbeek, J., Kaschner, K., Ben Rais Lasram, F., Aguzzi, J., et al. (2010). The biodiversity of the Mediterranean Sea: estimates, patterns, and threats. PLoS ONE 5:e11842. doi: 10.1371/journal.pone.0011842

Cook, S. C. and Bergquist, P. R. (2002). "Family irciniidae gray, 1867," in Systema Porifera: A Guide to The Classification of Sponges, eds J. N. A. Hooper and R. W. M. van Soest (New York, NY: Kluwer Academic/Plenum Publishers), 1022-1027.

Costello, M. J., Coll, M., Danovaro, R., Halpin, P., Ojaveer, H., and Miloslavich, P. (2010). A census of marine biodiversity knowledge, resources, and future challenges. PLoS ONE 5:e12110. doi: 10.1371/journal.pone.0012110

Damalas, D. (2002). Study of Pelagic Sharks Populations in the Eastern Mediterranean Sea. Master thesis, National and Kapodistrian University of Athens, Athens.

Damalas, D. (2009). Comparative Study on the Influence of Environmental Factors on the Distribution of Prionace Glauca (Blue Shark) and Xiphias gladius (Swordfish), of the Eastern Mediterranean Pelagic Ecosystem. Ph.D thesis, National and Kapodistrian University of Athens, Athens. Available online at: www.didaktorika.gr/eadd/handle/10442/24021

Damalas, D., and Megalofonou, P. (2012). Occurrences of large sharks in the open waters of the south-eastern Mediterranean Sea. J. Nat. Hist. 46, 2701-2723. doi: 10.1080/00222933.2012.716864

Dando, P. R., Aliani, S., Arab, H., Bianchi, C. N., Brehmer, M., Cocito, S., et al. (2000). Hydrothermal studies in the Aegean Sea. Phys. Chem. Earth 25, 1-8. doi: 10.1016/S1464-1909(99)00112-4

Dendrinos, P. (2011). Contribution to the Study of the Mediterranean Monk Seal's (Monachus monachus) Ecology and Biology at the Island Complex of Northern Sporades, Greece. Ph.D thesis, National and Kapodistrian University of Athens, Athens. Available online at: https://www.didaktorika.gr/eadd/handle/10442/ 35243

Dendrinos, P., Karamanlidis, A. A., Kotomatas, S., Paravas, V., and Adamantopoulou, S. (2008). Report of a new Mediterranean monk seal (Monachus monachus) breeding colony in the Aegean Sea, Greece. Aquat. Mamm. 34, 355-361. doi: 10.1578/AM.34.3.2008.355

Dimas, X., Fakiris, E., Christodoulou, D., Zoura, D., Papatheodorou, G., Paximadis, G., et al. (2015). "Mapping of high priority marine habitats in the coastal zone of Gyaros Isl," in Proceedings of the 11th Symposium on Oceanography and Fisheries (Mytilene), 1033-1036.

ETC/BD (2010). EU Additional Guidelines for Assessing Sufficiency of Natura 2000 (European Topic Centre on Biological Diversity) Proposals (SCIs) for Marine Habitats and Species. Available online at: http://bd.eionet.europa.eu/activities/ Natura_2000/pdfs/Additional_marine_guidelines.pdf

Fakiris, E. (2012). Developing Computational Tools for the Processing and Analysis of Marine Geophysical Data. Applications to Ionian Sea, Aegean Sea and Patraikos Gulf, Greece. Ph.D. Thesis, Geology Department, University of Patra, Patra.

Frantzis, A. (2009). Cetaceans in Greece: Present Status of Knowledge. Initiative for the Conservation of Cetaceans in Greece. Technical Report, Athens.

Fraschetti, S., Terlizzi, A., and Boero, F. (2008). How many habitats are there in the sea (and where)? J. Exp. Mar. Biol. Ecol. 366, 109-115. doi: 10.1016/j.jembe.2008.07.015

Fric, J., Portolou, D., Manolopoulos, A., and Kastritis, T. (2012). Important Areas for Seabirds in Greece. LIFE07 NAT/GR/000285 - Hellenic Ornithological Society (HOS/BirdLife Greece), Athens.

General Administration for Sustainable Fisheries (2016). List of Coastal Lagoons. Available online at: www.alieia.minagric.gr/node/27

Georgiadis, M., Papatheodorou, G., Tzanatos, E., Geraga, M., Ramfos, A., Koutsikopoulos, C., et al. (2009). Coralligène formations in the eastern Mediterranean Sea: morphology, distribution, mapping and relation to fisheries in the southern Aegean Sea (Greece) based on high-resolution acoustics. J. Exp. Mar. Biol. Ecol. 368, 44-58. doi: 10.1016/j.jembe.2008.10.001

Geraga, M., Papatheodorou, G., Agouridis, C., Kaberi, H., Iatrou, M., Christodoulou, D., et al. (2016). Palaeoenvironmental implications of a marine geoarchaeological survey conducted in the SW Argosaronic gulf, Greece. J. Archaeol. Sci. Rep. 12, 805-818. doi: 10.1016/j.jasrep.2016. 08.004 
Gerovasileiou, V., and Voultsiadou, E. (2012). Marine caves of the Mediterranean Sea: a sponge biodiversity reservoir within a biodiversity hotspot. PLoS ONE 7:e39873. doi: 10.1371/journal.pone. 0039873

Gerovasileiou, V., Chintiroglou, C., Vafidis, D., Koutsoubas, D., Sini, M., Dailianis, T., et al. (2015). Census of biodiversity in marine caves of the Eastern Mediterranean Sea. Mediterr. Mar. Sci. 16, 245-265. doi: 10.12681/ mms.1069

Gerovasileiou, V., Martínez, A., Álvarez, F., Boxshall, G., Humphreys, W., and Jaume, D. (2016). World register of marine cave species (WoRCS): a new thematic species database for marine and anchialine cave biodiversity. RIO 2:e10451. doi: 10.3897/rio.2.e10451

Giakoumi, S., Grantham, H. S., Kokkoris, G. D., and Possingham, H. P. (2011). Designing a network of marine reserves in the Mediterranean Sea with limited socio-economic data. Biol. Conserv. 144, 753-763. doi: 10.1016/j.biocon.2010.11.006

Giakoumi, S., Katsanevakis, S., Vassilopoulou, V., Panayotidis, P., Kavadas, S., Issaris, Y., et al. (2012a). Could European marine conservation policy benefit from systematic conservation planning? Aquat. Conserv Mar. Freshw. Ecosyst. 22, 762-775. doi: $10.1002 /$ aqc. 2273

Giakoumi, S., Mazor, T., Fraschetti, S., Kark, S., Portman, M., Coll, M., et al. (2012b). Advancing marine conservation planning in the Mediterranean Sea. Rev. Fish Biol. Fish. 22, 943-949. doi: 10.1007/s11160-012-9272-8

Giakoumi, S., Scianna, C., Plass-Johnson, J., Micheli, F., Grorud-Colvert, K., Thiriet, P., et al. (2017). Ecological effects of full and partial protection in the crowded Mediterranean Sea: a regional meta-analysis. Sci. Rep. 7:8940. doi: 10.1038/s41598-017-08850-w

Giakoumi, S., Sini, M., Gerovasileiou, V., Mazor, T., Beher, J., Possingham H. P., et al. (2013). Ecoregion-based conservation planning in the Mediterranean: dealing with large-scale heterogeneity. PLoS ONE 8:e76449. doi: 10.1371 /journal.pone. 0076449

Giannoulaki, M., Markoglou, E., Valavanis, V. D., Alexiadou P., Cucknell, A. C., Frantzis, A. (2016). Linking small pelagic fish and cetacean distribution to model suitable habitat for coastal dolphin species, Delphinus delphis and Tursiops truncatus, in the Greek Seas (Eastern Mediterranean). Aquat. Conserv Mar. Freshw. Ecosyst. 27, 436-451. doi: 10.1002/ aqc. 2669

Halpern, B. S., Walbridge, S., Selkoe, K. A., Kappel, C. V., Micheli, F., D'Agrosa, C., et al. (2008). A global map of human impact on marine ecosystems. Science 319, 948-952. doi: 10.1126/science.1149345

Heim, I., Nickel, M., and Brümmer, F. (2007). "Molecular markers for species discrimination in poriferans: a case study on species of the genus Aplysina," in Porifera Research: Biodiversity, Innovation and Sustainability, eds M. R. Custódio, G. Lôbo-Hajdu, E. Hajdu, and G. Muricy (Rio de Janeiro: Museu Nacional, Série Livros), 361-371.

Ignatiades, L., Psarra, S., Zervakis, V., Pagou, K., Souvermezoglou, E., Assimakopoulou G., et al. (2002). Phytoplankton size-based dynamics in the Aegean Sea (Eastern Mediterranean). J. Mar. Syst. 36, 11-28. doi: 10.1016/S0924-7963(02)00132-X

Issaris, Y., Katsanevakis, S., Pantazi, M., Vassilopoulou, V., Panayotidis, P., and Kavadas, S. (2012). Ecological mapping and data quality assessment for the needs of ecosystem-based marine spatial management: case study Greek Ionian Sea and the adjacent gulfs. Mediterr. Mar. Sci. 13, 297-311. doi: $10.12681 / \mathrm{mms} .312$

Jackson, S. and Lundquist, C. J. (2016). Limitations of biophysical habitats as biodiversity surrogates in the Hauraki Gulf Marine Park. Pac. Conserv. Biol. 22, 159-172. doi: 10.1071/PC15050

Karamanlidis, A. A., Dendrinos, P., Fernández de Larrinoa, P., Gücü, A. C., Johnson, W. M., Kiraç, C. O., et al. (2015). The Mediterranean monk seal Monachus monachus: status, biology, threats, and conservation priorities. Mammal Rev. 46, 92-105. doi: 10.1111/mam.12053

Katsanevakis, S., and Thessalou-Legaki, M. (2009). "Documenting the presence of protected species in Souda Bay," in Proceedings of the 9th Hellenic Symposium on Oceanography and Fisheries (Patra), 745-750.

Katsanevakis, S., Lefkaditou, E., Galinou-Mitsoudi, S., Koutsoubas D., and Zenetos A. (2008). Molluscan species of minor commercial interest in Hellenic seas: distribution, exploitation and conservation status. Mediterr. Mar. Sci. 9, 77-118. doi: $10.12681 / \mathrm{mms} .145$
Katsanevakis, S., Levin, L., Coll, M., Giakoumi, S., Shkedi, D., Mackelworkth, P., et al. (2015). Marine conservation challenges in an era of economic crisis and geopolitical instability: the case of the Mediterranean Sea. Mar. Policy 51,31-39. doi: 10.1016/j.marpol.2014.07.013

Katsanevakis, S., Poursanidis, D., Issaris, Y., Panou, A., Petza, D., and Vassilopoulou, V. (2011a). "Protected" marine shelled molluscs: thriving in Greek seafood restaurants. Mediterr. Mar. Sci. 12, 429-438. doi: $10.12681 / \mathrm{mms} .42$

Katsanevakis, S., Stelzenmüller, V., South, A., Sørensen, T. K., Jones, P. J. S., Kerr, S., et al. (2011b). Ecosystem-based marine spatial management: review of concepts, policies, tools, and critical issues. Ocean Coast. Manage. 54, 807-820. doi: 10.1016/j.ocecoaman.2011.09.002

Kefalas, E. and Castritsi-Catharios, J. (2007). Taxonomy of some sponges (Porifera: Demospongiae) collected from the Aegean Sea and description of a new species. J. Mar. Biol. Assoc. U.K. 87, 1-12. doi: 10.1017/S002531540705206X

Kilias, S. P., Nomikou, P., Papanikolaou, D., Polymenakou, P. N., Godelitsas, A., and Argyraki, A. (2013). New insights into hydrothermal vent processes in the unique shallow-submarine arc-volcano, Kolumbo (Santorini), Greece. Sci. Rep. 3:2421. doi: $10.1038 /$ srep02421

Laborel, J. (1987). Marine biogenic constructions in the Mediterranean. Sci. Rep. Port-Cros. Natl. Park 13, 97-126.

Letessier, T. B., Bouchet, P. J., and Meeuwig, J. J. (2017). Sampling mobile oceanic fishes and sharks: implications for fisheries and conservation planning. Biol. Rev. 92, 627-646. doi: 10.1111/brv.12246

Levin, N., Coll, M., Fraschetti, S., Gal, G., Giakoumi, S., and Göke, C. (2014). Biodiversity data requirements for systematic conservation planning in the Mediterranean Sea. Mar. Ecol. Prog. Ser. 508, 261-281. doi: 10.3354/meps10857

Lourie, S. A. and Vincent, A. C. J. (2004). Using biogeography to help set priorities in marine conservation. Conserv. Biol. 18, 1004-1020. doi: 10.1111/j.1523-1739.2004.00137.x

Lykousis, V., Chronis, G., Tselepidis, A., Price, N. B., Theocharis, A., SikouFrangou, I., et al. (2002). Major outputs of the recent multidisciplinary biogeochemical researches undertaken in the Aegean Sea. J. Mar. Syst. 33-34, 313-334. doi: 10.1016/S0924-7963(02)00064-7

Margules, C. R. and Pressey, R. L. (2000). Systematic conservation planning. Nature 405, 243-253. doi: 10.1038/35012251

Martin, C. S., Giannoulaki, M., De Leo, F., Scardi, M., Salomidi, M., Knittweis, L., et al. (2014). Coralligenous and maërl habitats: predictive modelling to identify their spatial distributions across the Mediterranean Sea. Sci. Rep. 4:5073. doi: $10.1038 /$ srep05073

MedPAN and UNEP/MAP-SPA/RAC (2016). The 2016 Status of Marine Protected Areas in the Mediterranean: Main Findings. Available online at: www.medmpaforum.org/sites/default/files/medpan-forum_mpa_2016_-_ brochure_a4_en_web.pdf

Megalofonou, P., Damalas, D., Yannopoulos, C., De Metrio, G., Deflorio, M., De La Serna, et al. (2000). By-Catches and Discards of Sharks in the Large Pelagic Fisheries in the Mediterranean Sea. Final Report of the Project No. 97/50 DG $\mathrm{XIV/C1}$. Commission of the European Communities.

Micheli, F., Halpern, B. S., Walbridge, S., Ciriaco, S., Ferretti, F., Fraschetti, F., et al. (2013a). Cumulative human impacts on Mediterranean and Black Sea marine ecosystems: assessing current pressures and opportunities. PLoS ONE 8:e79889. doi: 10.1371/journal.pone.0079889

Micheli, F., Levin, N., Giakoumi, S., Katsanevakis, S., Abdulla, A., Coll, M., et al. (2013b). Setting priorities for regional conservation planning in the Mediterranean Sea. PLoS ONE 8:e59038. doi: 10.1371/journal.pone. 0059038

Moilanen, A., Wilson, K. A., and Possingham, H. P., (eds.) (2009). Spatial Conservation Prioritization: Quantitative Methods and Computational Tools, Vol. 6. Oxford: Oxford University Press.

Nicolaidou, A., Reizopoulou, S., Koutsoubas, D., Orfanidis, S., and Kevrekidis, T. (2005). Biological components of Greek lagoonal ecosystems: an overview. Mediterr. Mar. Sci. 6, 31-50. doi: 10.12681/ mms. 184

Nomikou, P., Carey, S., Papanikolaou, D., Croff Bell, K., Sakellariou, D., Alexandri, M., et al. (2012). Submarine volcanoes of the Kolumbo volcanic zone NE of Santorini Caldera, Greece. Glob. Planet. Change 90-91, 135-151. doi: 10.1016/j.gloplacha.2012.01.001 
Nomikou, P., Papanikolaou, D., Alexandri, M., Sakellariou, D., and Roussakis, G. (2013). Submarine volcanoes along the Aegean Volcanic Arc. Tectonophysics 507-508, 123-146. doi: 10.1016/j.tecto.2012.10.001

Notarbartolo di Sciara, G., Adamantopoulou, S., Androukaki, E., Dendrinos, P., Karamanlidis, A. A., Paravas, V., et al. (2009). National Strategy and Action Plan for the Conservation of the Mediterranean Monk Seal in Greece, 2009-2015. Athens: MOm. Available online at: www.monachus-guardian.org/library/notarb09b.pdf

Otero, M. M., Numa, C., Bo, M., Orejas, C., Garrabou, J., Cerrano, C., et al. (2017). Overview of the Conservation Status of Mediterranean Anthozoans. Malaga: IUCN.

Papatheodorou, G., Geraga, M., Christodoulou, D., Iatrou, M., Fakiris, E., Heath. S., et al. (2014). A marine geoarchaeological survey, cape Sounion, Greece: preliminary results. Mediterr. Archaeol. Archaeometry 14, 357-371.

Pérès, J.-M., and Picard, J. (1958). Recherches sur les peuplements benthiques de la Méditerranée nord-orientale. Résult. Scientifiq. Campag. Calypse. 3, 213-291.

Petrakis, G., Chilari, A., and Kavadas, S. (2001). Evaluation of the Consequences of the Prohibition of the Beach Seine Fishery in Greece. Athens: Ministry of Agriculture, NCMR.

Petrakis, G., Kavadas, S., Siapatis, A., Segovia, M., Lefkaditou, E., Sourlas, E. (2009). Assessment of Impacts of the Boat Seine Fishery on Fisheries Resources. Technical report, HCMR, Athens.

Pierson, J. C., Barton, P., Lane, P., and Lindenmayer, D. B. (2015). Can habitat surrogates predict the response of target species to landscape change? Biol. Conserv. 184, 1-10. doi: 10.1016/j.biocon.2014.12.017

PISCO (Partnership for Interdisciplinary Studies of Coastal Oceans) and UNS (University of Nice Sophia Antipolis) (2016). The Science of Marine Protected Areas, $3 r d E d n$. Mediterranean. Available online at: www.piscoweb.org

Possingham H. P., Wilson, K. A., Andelman, S. J., and Vynne, C. H. (2006), "Protected areas: Goals, limitations and design" in Principles of Conservation Biology, 3rd Edn., eds M. J. Groom, G. K. Meffe, and C. R. Carroll (Sunderland, MA: Sinauer Associates, Inc.), 509-533.

Reeves, R., and Notarbartolo di Sciara, G. (2006). The Status and Distribution of Cetaceans in the Black Sea and Mediterranean Sea. Malaga: IUCN Centre for Mediterranean Cooperation.

Sakellariou, D. and Papoulia, I. (2005). "Geotectonic setting and seismicity" in State of the Hellenic Marine Environment, eds E. Papathanassiou and A. Zenetos (Athens: Hellenic Centre for Marine Research Publications), 13-15.

Sakellariou, D., Lykousis, V., Karageorgis, A., and Anagnostou, C. (2005). "Geomorpholgy and tectonic structure," in State of the Hellenic Marine Environment, eds E. Papathanassiou and A. Zenetos (Athens: Hellenic Centre for Marine Research Publications), 16-20.

Salomidi, M., Giakoumi, S., Gerakaris, V., Issaris, Y., Sini, M., and Tsiamis, K. (2016). Setting an ecological baseline prior to the bottom-up establishment of a marine protected area in Santorini Island, Aegean Sea. Mediterr. Mar. Sci. 17, 720-737. doi: 10.12681/mms.1802

Salomidi, M., Katsanevakis, S., Borja, A., Braeckman, U., Damalas, D., Galparsoro, I., et al. (2012). Assessment of goods and services, vulnerability, and conservation status of European seabed biotopes: a stepping stone towards ecosystem-based marine spatial management. Mediterr. Mar. Sci. 13, 49-88. doi: $10.12681 / \mathrm{mms} .23$

Salomidi, M., Smith, C., Katsanevakis, S., Panayotidis, P., and Papathanassiou, V. (2009). "Some observations on the structure and distribution of several gorgonian assemblages in the Eastern Mediterranean Sea," in Proceedings of the 1st Mediterranean Symposium on Coralligenous Conservation and Other Calcareous Bio-Concretions of the Mediterranean Sea (Tabarka), 242-245.

Salomidi, M., Zibrowius, H., Issaris, Y., and Milionis, K. (2010). Dendrophyllia in Greek waters, Mediterranean Sea, with the first record of D. ramea (Cnidaria, Scleractinia) from the area. Mediterr. Mar. Sci. 11, 189-194. doi: $10.12681 / \mathrm{mms} .102$

Sigurdsson, H., Carey, S., Alexandri, M., Vougioukalakis, G., Croff, K., Roman, C., et al. (2006). Marine investigations of Greece's Santorini volcanic field. EOS 87, 337-339. doi: 10.1029/2006EO340001

Silvertown, J. (2009). A new dawn for citizen science. Trends Ecol. Evol. 24, 467-471. doi: 10.1016/j.tree.2009.03.017

Sini, M., Kipson, S., Linares, C., Koutsoubas, D., and Garrabou, J. (2015). The yellow gorgonian Eunicella cavolini: demography and disturbance levels across the Mediterranean Sea. PLoS ONE 10:e0126253. doi: 10.1371/journal.pone.0126253

Smith, C., Sakellariou, D., McCoy, F., and Wachsmann, S. (2009). "Deep coral environments south of Crete," in Proceedings of the 9th Symposium on Oceanography and Fisheries (Patra), 665-668.

Spalding, M. D., Fox, H. E., Allen, G. R., Davidson, N., Ferdana, Z. A., Finlayson, M., et al. (2007). Marine ecoregions of the world: a bioregionalization of coastal and shelf areas. Bioscience 57, 573-583. doi: 10.1641/B570707

Stelzenmüller, W., Breen, P., Stamford, T., Thomsen, F., Badalamenti, F., Borja, A., et al. (2013). Monitoring and evaluation of spatially managed areas: a generic framework for implementation of ecosystem based marine management and its application. Mar. Policy 37, 149-164. doi: 10.1016/j.marpol.2012. 04.012

Taviani, M., Vertino, A., López Correa, M., Savini, A., De Mol, B., Remia, A., et al. (2011). Pleistocene to recent scleractinian deep-water corals and coral facies in the Eastern Mediterranean. Facies 57, 579-603. doi: 10.1007/s10347-010-0247-8

Telesca, L., Belluscio, A., Criscoli, A., Ardizzone, G., Apostolaki, E. T., Fraschetti, S., et al. (2015). Seagrass meadows (Posidonia oceanica) distribution and trajectories of change. Sci. Rep. 5:12505. doi: 10.1038/srep 12505

UNEP/MAP (2009). UNEP(DEPI)/MED IG.19/8. Decision IG.20/4: Implementing MAP Ecosystem Approach Roadmap: Mediterranean Ecological and Operational Objectives, Indicators and Timetable for Implementing the Ecosystem Approach Roadmap. Athens:UNEP/MAP. Available online at: www.rac-spa.org/sites/default/files/doc_cop/decision_22.07_en.pdf

UNEP-MAP-RAC/SPA (2015a). Action Plan for the Conservation of Habitats and Species Associated with Seamounts, Underwater Caves and Canyons, Aphotic Hard Beds and Chemo-synthetic Phenomena in the Mediterranean Sea-Dark Habitats Action Plan. Tunis: UNEP RAC/SPA.

UNEP/MAP-RAC/SPA (2015b). Handbook for Interpreting Types of Marine Habitat for the Selection of Sites to be Included in the National Inventories of Natural Sites of Conservation Interest. Edited by D. Bellan-Santini, G. Bellan, G. Bitar, J.-G. Harmelin, G. Pergent. Tunis: RAC/SPA. 168p+Annex (Originally published in 2002).

UNEP-MAP-RAC/SPA (2017). Draft Guidelines for Inventorying and Monitoring Dark Habitats. Tunis: UNEPRAC/SPA.

Vafidis, D., Antoniadou, C., Voultsiadou. E., and Chintiroglou, C. (2014). Population structure of the protected fan mussel Pinna nobilis in the south Aegean Sea (eastern Mediterranean). J. Exp. Mar. Biol. Ecol. 94, 787-796. doi: $10.1017 /$ S0025315413001902

Vafidis, D., Koukouras, A., and Voultsiadou-Koukoura, E. (1994). Octocoral fauna of the Aegean Sea with a checklist of the Mediterranean species: new information, faunal comparisons. Ann. I. Océanogr. 70, 217-229.

Van Soest, R. W. M., Boury-Esnault, N., Vacelet, J., Dohrmann, M., Erpenbeck, D., De Voogd, N. J., et al. (2012). Global diversity of sponges (Porifera). PLoS ONE 7:e35105. doi: 10.1371/journal.pone.0035105

Voultsiadou, E. (1986). Systematics Zoogeography and Ecology of the Demosponges (Porifera) of the Continental Shelf in the North Aegean Sea. Ph.D. thesis, Aristotle University of Thessaloniki, Thessaloniki. Available online at: https:// www.didaktorika.gr/eadd/handle/10442/0169

Voultsiadou, E., Gerovasileiou, V., and Dailianis, T. (2013). "Extinction trends of marine species and populations in the Aegean Sea and adjacent ecoregions" in Marine Extinctions-Patterns and Processes, CIESM Workshop Monograph, Vol. 45, ed F. Briand (Monaco: CIESM Publisher), 59-74.

Voultsiadou, E., Kyrodimou, M., Antoniadou, C., and Vafidis, D. (2010). Sponge epibionts on ecosystem-engineering ascidians: the case of Microcosmus sabatieri. Estuar. Coast. Shelf Sci. 86, 598-606. doi: 10.1016/j.ecss.2009. 11.035

Voultsiadou, E., and Vafidis, D. (2007). Marine invertebrate diversity in Aristotle's zoology. Contrib. Zool. 76, 103-120.

Voultsiadou, E., Vafidis, D., and Antoniadou, Ch. (2008). Sponges of economical interest in the Eastern Mediterranean: an assessment of diversity and population density. J. Nat. Hist. 42, 529-543. doi: 10.1080/00222930701 835506

Watts, M. E., Ball, I. R., Stewart, R. S., Klein Eds, C. J., Wilson, K., Steinback, C., et al. (2009). Marxan with zones: software for optimal conservation 
based land- and sea-use zoning. Environ. Model. Softw. 24, 1513-1521. doi: 10.1016/j.envsoft.2009.06.005

Weidema, B. P., and Wesnæs, M. S. (1996). Data quality management for life cycle inventories - an example of using data quality indicators. J. Clean. Prod. 4, 167-174. doi: 10.1016/S0959-6526(96)00043-1

WWF (2016). WWF Portal for the Dissemination of Environmental Information on Greek Island Wetlands. Available online at: www.oikoskopio.gr/ygrotopio/ general/list_files.php?category=dedomeva_gewbasewv\&lang=en_US

Zapata-Ramírez, P. A., Scaradozzim D., Sorbi, L., Palma, M., Pantaleo, U., Ponti, M., et al. (2013). Innovative study methods for the Mediterranean coralligenous habitats. Adv. Oceanogr. Limnol. 4, 102-119. doi: 10.4081/aiol.2013.5339

Zervakis, V., Georgopoulos, D., Karageorgis, A.P., and Theocharis, A. (2004). On the response of the Aegean Sea to climatic variability: a review. Int. J. Climatol. 24, 1845-1858. doi: 10.1002/joc.1108

Zibrowius, H (1979). Campagne de la Calypso en Méditerranée nord-orientale (1955, 1956, 1960, 1964). 7. Scléractiniaires. Ann. I. Océanogr. 55, 7-28.

Zibrowius, H. (1980). Les scléractiniaires de la Méditerranée et de l'Atlantique nord-oriental. Mem. Inst. Océanogr. Monaco 11, 1-284.
Conflict of Interest Statement: The authors declare that the research was conducted in the absence of any commercial or financial relationships that could be construed as a potential conflict of interest.

The reviewer HT declared a past co-authorship with one of the authors SK to the handling Editor.

Copyright (C) 2017 Sini, Katsanevakis, Koukourouvli, Gerovasileiou, Dailianis, Buhl-Mortensen, Damalas, Dendrinos, Dimas, Frantzis, Gerakaris, Giakoumi, Gonzalez-Mirelis, Hasiotis, Issaris, Kavadas, Koutsogiannopoulos, Koutsoubas, Manoutsoglou, Markantonatou, Mazaris, Poursanidis, Papatheodorou, Salomidi, Topouzelis, Trygonis, Vassilopoulou and Zotou. This is an open-access article distributed under the terms of the Creative Commons Attribution License (CC $B Y)$. The use, distribution or reproduction in other forums is permitted, provided the original author(s) or licensor are credited and that the original publication in this journal is cited, in accordance with accepted academic practice. No use, distribution or reproduction is permitted which does not comply with these terms. 